\title{
Wastewater Valorization: Practice around the World at Pilot- and Full-Scale
}

\author{
Anouk F. Duque ${ }^{1,2} \mathbb{D}$, Riccardo Campo ${ }^{3}\left(\mathbb{D}\right.$, Angeles Val del Rio ${ }^{4}$ and Catarina L. Amorim ${ }^{5, *(\mathbb{D})}$ \\ 1 Associate Laboratory i4HB-Institute for Health and Bioeconomy, NOVA School of Science and Technology, \\ NOVA University Lisbon, 1099-085 Lisboa, Portugal; af.duque@fct.unl.pt \\ 2 UCIBIO-Applied Molecular Biosciences Unit, Department of Chemistry, NOVA School of Science and \\ Technology, NOVA University Lisbon, 1099-085 Lisboa, Portugal \\ 3 DICEA-Dipartimento di Ingegneria Civile e Ambientale, Università degli Studi di Firenze, Via di S. Marta 3, \\ 50139 Florence, Italy; riccardo.campo@unifi.it \\ 4 Department of Chemical Engineering, CRETUS Institute, Universidade de Santiago de Compostela, Rúa Lope \\ Gómez de Marzoa s/n, E-15705 Santiago de Compostela, Spain; mangeles.val@usc.es \\ 5 CBQF-Centro de Biotecnologia e Química Fina-Laboratório Associado, Escola Superior de Biotecnologia, \\ Universidade Católica Portuguesa, Rua Diogo Botelho 1327, 4169-005 Porto, Portugal \\ * Correspondence: camorim@ucp.pt; Tel.: +351-226-196-200
}

check for updates

Citation: Duque, A.F.; Campo, R.; Val del Rio, A.; Amorim, C.L. Wastewater Valorization: Practice around the World at Pilot- and Full-Scale. Int. J. Environ. Res. Public Health 2021, 18, 9466. https:// doi.org/10.3390/ijerph18189466

Academic Editor: Paul B. Tchounwou

Received: 13 August 2021

Accepted: 3 September 2021

Published: 8 September 2021

Publisher's Note: MDPI stays neutral with regard to jurisdictional claims in published maps and institutional affiliations.

Copyright: (c) 2021 by the authors. Licensee MDPI, Basel, Switzerland. This article is an open access article distributed under the terms and conditions of the Creative Commons Attribution (CC BY) license (https:// creativecommons.org/licenses/by/ $4.0 /)$.

\begin{abstract}
Over the last few years, wastewater treatment plants (WWTPs) have been rebranded as water resource recovery facilities (WRRFs), which recognize the resource recovery potential that exists in wastewater streams. WRRFs contribute to a circular economy by not only producing clean water but by recovering valuable resources such as nutrients, energy, and other bio-based materials. To this aim, huge efforts in technological progress have been made to valorize sewage and sewage sludge, transforming them into valuable resources. This review summarizes some of the widely used and effective strategies applied at pilot- and full-scale settings in order to valorize the wastewater treatment process. An overview of the different technologies applied in the water and sludge line is presented, covering a broad range of resources, i.e., water, biomass, energy, nutrients, volatile fatty acids (VFA), polyhydroxyalkanoates (PHA), and exopolymeric substances (EPS). Moreover, guidelines and regulations around the world related to water reuse and resource valorization are reviewed.
\end{abstract}

Keywords: wastewater; valorization; recycling; reuse; resource recovery; sludge

\section{Introduction}

The water demand is increasing worldwide. In fact, the world population is expected to reach over 9 billion in 2050, which will increase the demand for natural resources. Consequently, the global water demand is estimated to increase by 55\% in 2050, mainly due to the higher water needs for activities such as manufacturing, thermal electricity generation, and domestic use [1]. As such, wastewater treatment plants (WWTP) have an important role in the safe return of water into the water cycle. In Europe, the adoption of the Urban Waste-Water Treatment Directive in 1991 (Council Directive 91/271/EEC) promoted the improvement of urban wastewater treatment, increasing the building of collection facilities and the proportion of the population connected to them. In fact, in 2017, for most of the EU-27 countries, at least $80 \%$ of their national population was connected to urban WWTPs. The main purpose of WWTPs is to produce high-quality water to be discharged into the environment. For that purpose, the chemical composition, health-related pollutants (e.g., pathogens), and aesthetic qualities of the treated water must be considered to minimize the environmental impact of the treated wastewater discharge. Although the traditional importance of WWTPs was to protect the environment and population health and wellbeing, in recent decades, the need for more sustainable processes has led to a paradigm shift in the water sector consisting of transforming wastewater from an unwanted waste stream to a 
valuable resource [2]. The current needs of modern societies have encouraged the scientific community to search for a wide range of technological solutions that have allowed for more circular resource flows, which aim at the resource recovery (e.g., water, nutrients, energy, and biomaterials) from wastewater. This transition to a circular economy model promotes a reduce-reuse-recycle strategy for waste management, contributing for the 2030 Agenda for Sustainable Development [3]. Therefore, the concept and term "WWTP" is being replaced by "WRRF" (Wastewater Resource Recovery Facility) nowadays [4].

The adoption of the circular economy principles in wastewater management can promote resource recovery and reuse, which can transform sanitation from a costly service to one that is more self-sustainable while adding value to the economy. To raise awareness on this issue among the stakeholders and practitioners involved in wastewater planning, financing, and management (e.g., water utilities, policy makers, or even ministries of planning and finance), a report was launched by the World Bank Water Global Practice Initiative that highlighted the different actions that need to be adopted [5]:

(1) Develop wastewater initiatives as part of a basin planning framework to maximize benefits, improve efficiency and resource allocation, and engage stakeholders;

(2) Build utilities of the future by shifting away from WWTPs to WRRFs, thus realizing the value of wastewater;

(3) Explore and support the development of innovative financing and sustainable business models in the water sector;

(4) Implement the necessary policy, institutional, and regulatory frameworks to promote the paradigm shift.

Resource recovery from wastewater treatment technologies at a larger scale is still scarcely reported. In this context, this review paper aims to provide a global and comprehensive view of the status of resource recovery at pilot- and full-scale WRRFs worldwide, with special focus on water recovery as the main valuable compound and also highlighting the importance of recovering other resources, namely biomass (as microalgae and single cell protein), energy (as biogas), nutrients (as fertilizers), or more novel biomaterials such as volatile fatty acids (VFA), polyhydroxyalkanoates (PHA), and exopolymeric substances (EPS) (Figure 1). Apart from the resources recovered from wastewater that will be described in this review paper, there are reports on the literature on the recovery of other types of resources with industrial interest, namely metals, sludge-based adsorbents, materials for the building sector, and proteins and enzymes [6-9] that will not be included in this review paper.

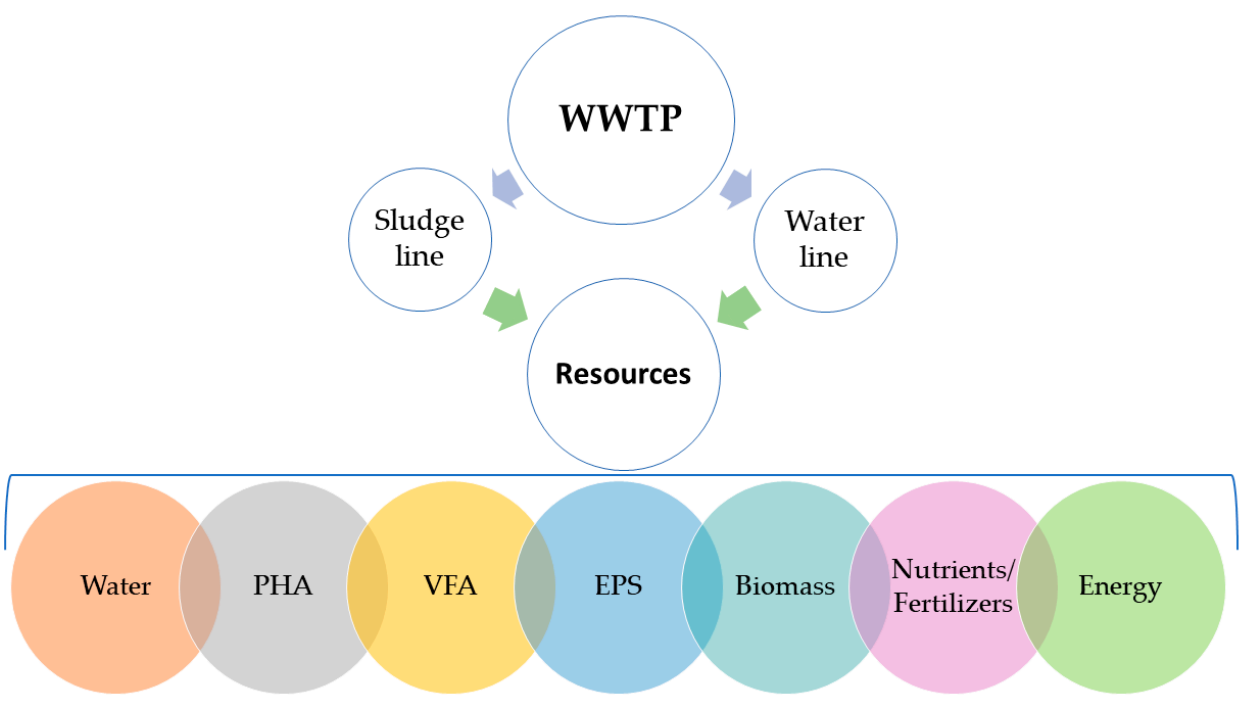

Figure 1. General overview of the review article: from wastewater to resource. 
The treatment of wastewater by traditional (activated sludge) or novel technologies (such as biofilm systems such as granular sludge) based on the use of biological processes is often preferred/adopted because of their cheaper operational expenditures (i.e., no chemicals required) and their lower environmental impact in comparison to physicochemical processes. For this reason, the recovery of valuable products in biological-based processes can be made directly from the sewage (water line) or indirectly from the waste sludge that is produced (sludge line). Based on the information collected in the literature for the target recovered products, a comparative analysis between the routes applied to the water and sludge lines is provided (Figure 2). The feasibility of the technologies applied at a larger scale to recover added-value products differs between the water and sludge lines (Figure 2). Usually, it seems to be preferable to concentrate in the sludge the organic (i.e., VFA, PHA, EPS) and the inorganic (i.e., nutrients) compounds present in the wastewater to then obtain the biomaterials and nutrient-enriched streams from that sludge.

\begin{tabular}{|c|c|c|}
\hline & Water line & Sludge line \\
\hline Water & $+4+$ & + \\
\hline Biomass & $+4+$ & $+4+$ \\
\hline Nutrients/fertilizers & +4 & $+4+$ \\
\hline Energy & $4+$ & $+4+$ \\
\hline VFA & +4 & $+4+$ \\
\hline PHA & 4 & 44 \\
\hline EPS & n.r. & +4 \\
\hline
\end{tabular}

n.r. - not reported

Figure 2. Summary of the resources recovered from wastewater reviewed in this study, with indication of the relative abundance of routes applied to the water and sludge lines.

\section{Water}

The difference between water availability and water demand has caused water stress in different regions around the world, especially in those areas where water is scarce. For this reason, the recovery of water after its use is of extreme importance (water reclamation). Treated wastewater is one of the most available water resources that is constantly being produced and, its use for certain activities can considerably reduce the consumption of potable water. Reclaimed water can be used for various purposes including agriculture (irrigation), industrial processes, or even as drinking water after the application of a proper treatment chain (tertiary treatments, advanced oxidation process, ultrafiltration, reverse osmosis, etc.) in order to avoid the presence of pathogens. However, the most common use is for irrigation because of the stringent limits imposed for the other uses and the high volumes of water needed for this activity. In fact, according to the Food and Agriculture Organization of the United Nations (FAO), agriculture accounts for approximately 70\% of all of the water withdrawn from natural water resources, which is much higher than the amount observed for other sectors (20\% industrial and 10\% municipal) [10]. Therefore, even if all of the industrially and municipally consumed water was reused, it would only cover approximately $43 \%$ of the amount needed for agriculture. For this reason, the reuse of wastewater for drinking water or industrial applications is not as cost effective as it is for irrigation. However, in the review of Ofori and colleagues [11], the inconveniences of 
wastewater reuse for irrigation are analyzed and highlight, for example, the impacts on the soil ( $\mathrm{pH}$ and salinity changes, heavy metals accumulation, etc.), public health problems related to the presence of potential pathogens, and the presence of emerging contaminants such as microplastics, antibiotic resistant genes, and antibiotic resistant bacteria.

The greatest obstacles for wastewater reuse are related to technical (because it is more complicated to treat wastewater than it is to catch water from natural resources), economical (because wastewater treatment is normally expensive), social (because it is perceived as being more risky than beneficial), and political (because, for example, of the trade barriers for food products grown with reused water) issues [12]. Despite these obstacles, some successful examples of municipal and industrial wastewater reuse can be found around the world, which can serve to encourage new initiatives, especially in those regions where water scarcity will be a problem in the future.

\subsection{Municipal Wastewater Reuse}

One of the most encouraging processes for wastewater reuse was the pioneering program launched in 1968 in the city of Windhoek, in Namibia, which is the first city in the world to recycle wastewater for drinking water purposes [13]. In this city, the lack of water resources nearby, the low rate of rainfall (approximately $360 \mathrm{~mm} /$ year), the high rate of evaporation (ca. $3700 \mathrm{~mm} /$ year), and the continuous population growth (around $5 \%$ year) have forced the acceptance of alternative water sources, such as reclaimed water. Throughout the years, in order to meet the water demands due to the growing population, the city has been continuously adopting alternative strategies to increase the existing supply sources [13].

Israel is one of the countries with the highest water scarcity in the world. Currently, to alleviate this situation, desalination systems are used but, the use of reclaimed water has also emerged as an alternative source, satisfying around $25 \%$ of the country's necessities [14] In fact, Israel recycles about $90 \%$ of used water, which is about four times higher than that recycled in any other country. Most of this reclaimed water is used for irrigation, while 10\% is used for environmental purposes (e.g., increasing river flow and fire suppression), and $5 \%$ is discharged into the sea. Shafdan, in Tel Aviv, is the largest WWTP in Israel (average daily flow of about $360,000 \mathrm{~m}^{3} / \mathrm{d}$ in 2014) [14]. The treatment consists of an extended aeration activated sludge system with biological nitrogen removal, producing a highquality effluent with average values of $<6 \mathrm{mg} \mathrm{BOD} / \mathrm{L},<6 \mathrm{mg} \mathrm{TSS} / \mathrm{L},<6 \mathrm{mg} \mathrm{TKN} / \mathrm{L}$, and $<1 \mathrm{mg}$ TP/L. This effluent is infiltrated into a sand aquifer with an average retention time of 1 year, and it is then pumped and reused for unrestricted agricultural land application, covering more than $70 \%$ of the irrigation needs in that zone [15].

Other examples to illustrate wastewater reuse opportunities are presented in Table 1, which summarizes the main findings of several cities worldwide [16]. In all of these cases, the most significant motivation for wastewater reuse is water scarcity, but there are also concerns about preventing the pollution of water sources (by reducing the discharge of untreated wastewater) as well as about the recovery of added-value products such as energy and fertilizers. Although the proportion of wastewater reuse is relatively low in some cases (between 5-50\%), there are cities such as Aqaba (69\%) and Kampala (100\%), which can serve as guides, opening prospects for other cities [16].

\subsection{Industrial Wastewater Reuse}

The use of reclaimed water in industrial applications is often limited to its use in the same industry. The particularities of some industrial processes lead to the presence of some compounds in the produced effluents, preventing their use in some applications. The major benefits of wastewater reuse for the industries are economical, as reuse contributes to the reduction of the costs of potable water consumption and additional effluent treatment processes needed to fulfil the legal discharge limits, and social, because it increases water availability in the surrounding community and increases the environmental awareness, improving the social perception of the industry [17]. 
Table 1. Cities with wastewater resource recovery facilities. Adapted from [16].

\begin{tabular}{|c|c|c|c|c|c|c|c|}
\hline $\begin{array}{c}\text { City } \\
\text { (Country) }\end{array}$ & $\begin{array}{c}\text { Population } \\
2016\end{array}$ & $\begin{array}{c}\text { Wastewater } \\
\text { On-Site Sanita- } \\
\text { tion/Sewer } \\
\text { Service } \\
\text { Coverage }\end{array}$ & $\begin{array}{c}\text { Wastewater } \\
\text { Treatment }\end{array}$ & $\begin{array}{c}\text { Treated } \\
\text { Wastewater } \\
\text { Reused }\end{array}$ & $\begin{array}{c}\text { Energy } \\
\text { Recovered }\end{array}$ & $\begin{array}{l}\text { Fertilizer } \\
\text { Recovery }\end{array}$ & $\begin{array}{c}\text { Potential to } \\
\text { Reduce } \\
\text { Emissions from } \\
\text { Improved } \\
\text { Wastewater } \\
\text { Management }\end{array}$ \\
\hline $\begin{array}{l}\text { Aqaba } \\
\text { (Jordan) }\end{array}$ & 194,000 & $10 / 90 \%$ & $\begin{array}{c}100 \% \\
45 \mathrm{M} . \mathrm{L} / \mathrm{d}\end{array}$ & $69 \%$ & $100 \%$ & NO & $\begin{array}{l}81,000 \text { ton } \mathrm{CO}_{2} \\
\text { eq/year }\end{array}$ \\
\hline $\begin{array}{l}\text { Bangkok } \\
\text { (Thailand) }\end{array}$ & $5.6 \mathrm{M}$ & $60 / 40 \%$ & $\begin{array}{c}100 \% \\
1.3 \mathrm{~B} \mathrm{~L} / \mathrm{d}\end{array}$ & $5 \%$ & $62 \%$ & YES & $\begin{array}{c}638,000 \text { ton } \mathrm{CO}_{2} \\
\text { eq/year }\end{array}$ \\
\hline $\begin{array}{l}\text { Beijing } \\
\text { (China) }\end{array}$ & $21.7 \mathrm{M}$ & $5 / 95 \%$ & $\begin{array}{c}88 \% \\
4.4 \mathrm{~B} \mathrm{~L} / \mathrm{d}\end{array}$ & $15 \%$ & $45 \%$ & YES & $\begin{array}{l}1,044,000 \text { ton } \\
\mathrm{CO}_{2} \text { eq/year }\end{array}$ \\
\hline $\begin{array}{l}\text { Chennai } \\
\text { (India) }\end{array}$ & $8.5 \mathrm{M}$ & $100 \%$ & $\begin{array}{c}70 \% \\
769 \mathrm{M} \mathrm{L} / \mathrm{d}\end{array}$ & $49 \%$ & $77 \%$ & $\mathrm{NO}$ & $\begin{array}{c}235,000 \text { ton } \mathrm{CO}_{2} \\
\text { eq/year }\end{array}$ \\
\hline $\begin{array}{c}\text { Durban } \\
\text { (South African) }\end{array}$ & $3.7 \mathrm{M}$ & $84 / 16 \%$ & $\begin{array}{c}100 \% \\
108 \mathrm{M} \mathrm{L} / \mathrm{d}\end{array}$ & $44 \%$ & $8 \%$ & YES & $\begin{array}{c}438,000 \text { ton } \mathrm{CO}_{2} \\
\text { eq/year }\end{array}$ \\
\hline $\begin{array}{l}\text { Kampala } \\
\text { (Uganda) }\end{array}$ & $1.5 \mathrm{M}$ & $60 / 40 \%$ & $\begin{array}{c}100 \% \\
87 \mathrm{M} \mathrm{L} / \mathrm{d}\end{array}$ & $100 \%$ & $227,000 \mathrm{kWh} / \mathrm{y}$ & YES & $\begin{array}{c}114,000 \text { ton } \mathrm{CO}_{2} \\
\text { eq/year }\end{array}$ \\
\hline $\begin{array}{l}\text { Lima } \\
\text { (Peru) }\end{array}$ & $10 \mathrm{M}$ & $17 / 83 \%$ & $\begin{array}{c}15 \% \\
240 \mathrm{M} \mathrm{L} / \mathrm{d}\end{array}$ & $5 \%$ & Low & $\mathrm{NO}$ & $\begin{array}{c}652,000 \text { ton } \mathrm{CO}_{2} \\
\text { eq/year }\end{array}$ \\
\hline
\end{tabular}

Some industries can directly reuse wastewater whenever it is clean enough for the purpose for which it is being reused. For instance, the water used in cooling and heating processes normally contains low levels of contaminants. Thus, its reuse in the same industry for irrigation, washing, $\mathrm{pH}$ adjustment, or fire protection activities is feasible after a proper disinfection treatment in order to remove hazardous microorganisms such as legionella [18]. Nevertheless, a high percentage of water used in industrial processes cannot be reused directly and needs to be subject to a previous treatment. There are successful cases of wastewater treatment for its subsequent reuse in different industrial sectors (Table 2).

Table 2. Industrial wastewater treatment processes aiming at water reuse.

\begin{tabular}{|c|c|c|c|c|}
\hline Industrial Sector & Wastewater Source & Treatment & Reuse of the Treated Water & Reference \\
\hline Aquaculture & Fish tanks & $\begin{array}{c}\text { Mechanical filtration, } \\
\text { biological filtration, } \\
\text { oxygenation, and sterilization } \\
\text { (ozone or UV) }\end{array}$ & Refeed the fish tanks & [19] \\
\hline Brewery (beer) & $\begin{array}{l}\text { Effluent from anaerobic } \\
\text { digester }\end{array}$ & $\begin{array}{l}\text { Flotation, membrane } \\
\text { bioreactor, ultrafiltration, and } \\
\text { reverse osmosis }\end{array}$ & Drinking water production & [20] \\
\hline $\begin{array}{c}\text { Agro-food } \\
\text { (horticulture sector) }\end{array}$ & $\begin{array}{l}\text { Mixture of water } \\
\text { streams from vegetable } \\
\text { processing, cleaning } \\
\text { activities, and toilets }\end{array}$ & $\begin{array}{c}\text { Oil removal, activated sludge } \\
\text { process (with } \\
\text { pre-denitrification scheme), } \\
\text { sand filtration, membrane } \\
\text { ultrafiltration, and UV } \\
\text { sterilization }\end{array}$ & $\begin{array}{l}\text { Irrigation of the own } \\
\text { company fields }\end{array}$ & [21] \\
\hline Dairy & $\begin{array}{l}\text { Mixture of the powder } \\
(82 \%) \text { and the butter } \\
(18 \%) \text { effluent streams }\end{array}$ & $\begin{array}{l}\text { Grease removal pond, } \\
\text { anaerobic pond, and } \\
\text { membrane bioreactor } \\
\text { (ultrafiltration) with anoxic } \\
\text { and aerobic zones. }\end{array}$ & Irrigation & [22] \\
\hline
\end{tabular}

The land-based aquaculture sector is perhaps the most advanced sector in terms of reusing water with the application of recirculating aquaculture systems (RAS), which have been steadily developed over the past 30 years to minimize the water withdrawn, to control culture conditions, and to allow waste streams to be fully managed [23]. Yet, the recirculating aquaculture systems still need to address some challenges, such as the complex and costly engineered system designs [24]. 
Recently, the integrated Industrial-Urban Water-Reuse (IU-WA-RE) concept has attracted great attention [25]. This approach aims to substantially increase water-reuse by combining industrial and municipal wastewater flows. The high loads of wastewater generated in industrial parks after being adequately treated can then be reused for the irrigation of the surrounding urban areas, as municipal wastewater is usually not enough to cover the water requirements for urban areas for infrastructural purposes [25].

\subsection{Water Reuse Legislation}

In Europe, only a small proportion of treated wastewater is reused (1100 million $\mathrm{m}^{3} /$ year, while the potential is around 6000 million $\mathrm{m}^{3}$ /year), and the main application for its reuse is for irrigation purposes [26]. In fact, treated wastewater can be an important water source for agriculture, but its application should be carefully regulated to hinder the use of water with insufficient quality that can later pose danger to human health. From 1980 to 2020, the European Union has thus developed different directives of major importance for the water sector to protect the environment and human health and to regulate the water cycle. The first directives launched by the European Union aimed at protecting the environment from the adverse effects of urban wastewater discharge. In 2000, the Council Water Directive (2000/60/EC) highlighted the need for more sustainable water usage for the first time. It was only in 2020 that the European Union launched the regulation on water reuse, stating the minimum requirements for water reuse (Regulation (EU) 2020/741) [27]. However, some authors have criticized that this regulation does not sufficiently cover relevant risks to protect human and environmental health, and several key aspects were inadequately addressed, for example, concerns surrounding contaminants of emerging concern, the spread of antibiotic resistance, and disinfection by-products [28].

In the United States, there is a general framework under the Safe Drinking Water Act [29] and the Clean Water Act [30] to regulate water reuse. In fact, the Environmental Protection Agency (EPA) does not require or restrict any type of reuse, but the water stream that is to be reused should be adequately treated to meet "fit-for-purpose specifications" for its specific next use [31]. More recently, a National Water Reuse Action Plan (WRAP) was developed, which included specific actions to improve the use of reclaimed water in the nation, which only accounts for $1 \%$ of the water demand [32]. The latter indicates that reuse can cover different applications apart from irrigation, such as potable and nonpotable water supplies, groundwater storage and recharge, industrial processes, onsite non-potable use, saltwater intrusion barriers, and environmental restoration. The newly proposed actions were classified into eleven strategic themes [33]. Among others, "Science and Specifications" and "Technology Development" can be highlighted, where the salinity of reused water is one of the main concerns because salts are normally not removed in conventional WWTPs, and their presence further limits applications such as irrigation (Table 3).

Table 3. Summary of some actions from the National Water Reuse Action Plan in the United States.

\begin{tabular}{cc}
\hline Science and Specifications & Technology Development \\
\hline $\begin{array}{c}\text { Develop a list of constituents of concern and } \\
\text { acceptable levels (or ranges) in potable } \\
\text { water reuse. }\end{array}$ & $\begin{array}{c}\text { Develop consistent approval processes and } \\
\text { standards for new treatment technologies. }\end{array}$ \\
\hline $\begin{array}{c}\text { Develop guidelines for reviewing and permitting } \\
\text { fit-for-purpose reuse applications. }\end{array}$ & $\begin{array}{c}\text { Research science and technology gaps for } \\
\text { onsite urban and stormwater reuse. }\end{array}$ \\
\hline $\begin{array}{c}\text { Research fit-for-purpose specifications and data } \\
\text { gaps for oil and gas produced wastewater. }\end{array}$ & $\begin{array}{c}\text { Research management and use for brine } \\
\text { from reuse projects. }\end{array}$ \\
\hline $\begin{array}{c}\text { Develop a plan to manage and regulate high salt } \\
\text { loads and disposal options from reuse water. }\end{array}$ & \\
\hline
\end{tabular}


One of the states where the water scarcity forces water reuse is California. In this state, the volume of recycled water used has more than doubled in the last two decades, but water demand still exceeds supply [34]. If the energy use per water source is considered, in California, the water produced by wastewater treatment is cheaper than that produced from seawater or groundwater desalination systems [35].

Even though there are some constraints, the safe reuse of the treated wastewater, if well-managed, can significantly reduce potable water demand, thus contributing to more sustainable water use.

Australia is one of the regions in the world where water scarcity strongly influences water reuse, as pointed out in the review by Radcliffe and Page [36]. These authors revised the past, present, and future perspectives for water reuse in that country, highlighting the strong influence of drought periods and policies that have been adopted. For example, the millennium drought (2000-2009) boosted water recycling and desalination, with the construction of advanced purified recycled water plants for indirect potable reuse as well as dual pipe installations for drinking and recycled water. However, after the drought, the catchment of surface water was cheaper than recycled or desalinated water, and economic motivations decreased its reuse. The return of drought conditions in 2019 saw the desalination systems reactivated, and although indirect potable recycling schemes were adopted again, community debate on direct potable recycling needs to be addressed.

\section{Biomass}

Huge amounts of sludge are annually produced in WWTPs, which can represent an environmental problem if the sludge is not correctly disposed of. Moreover, its disposal also represents additional costs for WWTPs, as it is estimated that the costs of its processing accounts for approximately $50 \%$ of overall WWTP operating expenses [37]. Waste sludge is usually a heterogeneous solid material consisting of water, microorganisms, organic matter, inorganic, and organic compounds [37]. This composition thus offers great potential for valorization, which can then turn waste sludge disposal from a major cost into a source of profit for WWTPs. According to European Parliament and Council Directive 2008/98/EC [38], the reduction of waste production should be the priority in sludge waste management, followed by the use of waste for reuse, recycling, or other forms of recovery, and ultimately, only sludge waste disposal should be considered. To assist the wastewater sector to meet this waste management hierarchy, several strategies have emerged that allow the production of a set of different marketable outputs from waste sludge. Effective strategies to achieve sludge valorization include its use as a product or as a source for resource recovery, such as for nitrogen, phosphorous, or carbon (e.g., in the forms of VFAs, PHAs, or methane $\left.\left(\mathrm{CH}_{4}\right)\right)$, and examples of these processes will be addressed in the following sections. The valorization of waste sludge through the production of added-value products is an important step towards a more sustainable society, with the expectation being that in the near future, WWTPs will be able to be converted into biorefineries in which the "production" of treated water is no longer the sole requirement.

\subsection{Microalgae Biomass}

Microalgae based systems are ecofriendly and sustainable wastewater treatment options due to their effective capacity to treat both municipal and industrial wastewater while also allowing $\mathrm{CO}_{2}$ fixation, saving nutrient input, and producing microalgal biomass, which is a source of a myriad of value-added algae-derived bioproducts and biomaterials [39].

Several research works at laboratory-scale have demonstrated the extraordinary capabilities of microalgae to treat wastewater of various origins, either directly or after pre-treatment processes [40]. More recently, microalgal-bacterial sludge based processes have attracted increasing attention due to the mutualistic and symbiotic relationship that microalgae and bacteria can establish [41]. The oxygen produced via photosynthesis by the microalgae cells can be used by the bacteria to oxidize organic matter, thus allowing for 
the collaboration between the microalgae and aerobic bacteria in the same system. This is particularly promising, as it can decrease the costs of aeration and can also reduce carbon dioxide emissions.

Although there have been encouraging results for wastewater valorization using microalgae-based systems at laboratory-scale, outdoor pilot- and full-scale studies are still scarce, and obviously, there is a long journey ahead for the large-scale application of these systems. Nevertheless, research efforts have been made to assess the scale-up potential of microalgae cultivation within a conventional wastewater treatment sequence in outdoor photobioreactors (Table 4).

Table 4. Microalgae culturing in wastewater streams in pilot-scale photobioreactors.

\begin{tabular}{|c|c|c|c|}
\hline Stream Source & Type of Reactor & $\begin{array}{l}\text { Biomass } \\
\text { Productivity }\end{array}$ & Reference \\
\hline $\begin{array}{l}\text { Centrate resulting from sludge } \\
\text { dewatering of urban WWTP in } \\
\text { northern Italy }\end{array}$ & $\begin{array}{c}\text { Raceway pond } \\
\text { (Working volume of } 1200 \mathrm{~L} \text { ) }\end{array}$ & $5.5 \pm 7.4 \mathrm{~g} \mathrm{TSS} / \mathrm{m}^{2} / \mathrm{d}$ & {$[42]$} \\
\hline $\begin{array}{c}\text { Centrate resulting from the solid } \\
\text { fraction of piggery wastewater, } \\
\text { energy crops, and agricultural waste } \\
\text { co-digestion }\end{array}$ & $\begin{array}{c}\text { Raceway pond } \\
\text { (Working volume of } 880 \mathrm{~L} \text { ) }\end{array}$ & $8.2 \mathrm{~g} \mathrm{TSS} / \mathrm{m}^{2} / \mathrm{d}$ & [43] \\
\hline $\begin{array}{l}\text { Centrate resulting from sludge } \\
\text { dewatering from a municipal Bresso } \\
\text { WWTP, northern Italy }\end{array}$ & $\begin{array}{c}\text { Column reactor } \\
\text { (Working volume of } 85 \mathrm{~L} \text { ) }\end{array}$ & $50 \mathrm{mg}$ TSS $/ \mathrm{L} / \mathrm{d}$ & [44] \\
\hline $\begin{array}{l}\text { Centrate resulting from sludge } \\
\text { dewatering from a municipal Bresso } \\
\text { WWTP, northern Italy }\end{array}$ & $\begin{array}{l}\text { Bubble column reactor } \\
\text { (Working volume of } 82 \mathrm{~L} \text { ) }\end{array}$ & $40 \pm 62 \mathrm{mg}$ TSS$/ \mathrm{L} / \mathrm{d}$ & [45] \\
\hline $\begin{array}{l}\text { Centrate resulting from sludge } \\
\text { dewatering }(20 \%) \text { plus seawater }\end{array}$ & $\begin{array}{l}\text { Tubular photobioreactors } \\
\text { (Working volume of } 340 \mathrm{~L} \text { ) }\end{array}$ & $\begin{array}{l}0.60 \mathrm{~g} \text { biomass } / \mathrm{L} / \mathrm{d}(\text { at a } \\
\text { dilution rate of } 0.3 / \mathrm{d})\end{array}$ & [46] \\
\hline $\begin{array}{c}\text { Centrate resulting from sludge } \\
\text { dewatering from a municipal WWTP } \\
\text { plus crude glycerol }(1 \mathrm{~g} / \mathrm{L})\end{array}$ & Photobioreactor & $460 \mathrm{mg}$ TVS/L/d & [47] \\
\hline $\begin{array}{l}\text { Anaerobic digested starch processing } \\
\text { wastewater }\end{array}$ & $\begin{array}{l}\text { Airlift photobioreactor } \\
\text { (Working volume of } 890 \mathrm{~L}, 1.80 \mathrm{~m} \text { length } \\
\times 0.62 / 0.30 \mathrm{~m} \text { breadth } \times 1.10 \mathrm{~m} \text { height) }\end{array}$ & $0.37 \mathrm{~g} / \mathrm{L} / \mathrm{d}$ & [48] \\
\hline Raw dairy wastewater (25\%) & $\begin{array}{c}\text { Photobioreactors } \\
\text { (Working volume of } 40 \mathrm{~L}, 272 \mathrm{~cm} \\
\text { diameter } \times 1720 \mathrm{~cm} \text { height) }\end{array}$ & $110 \mathrm{mg} / \mathrm{L} / \mathrm{d}$ & [49] \\
\hline Dairy effluent & $\begin{array}{l}\text { High-Volume V-shaped pond (working } \\
\text { volume of } 3 \mathrm{~m}^{3} \text { ) }\end{array}$ & $171 \mathrm{~g} / \mathrm{m}^{2} / \mathrm{d}$ & {$[50]$} \\
\hline Dairy farm wastewater & $\begin{array}{c}\text { Single loop raceway } \\
(2.5 \mathrm{~m} \times 0.7 \mathrm{~m} \times 0.7 \mathrm{~m} \text { and mixed by } \\
\text { paddle wheel at } 20 \mathrm{rpm})\end{array}$ & $0.38 \pm 0.09 \mathrm{~g} / \mathrm{L} / \mathrm{d}$ & [51] \\
\hline $\begin{array}{c}\text { Swine wastewater (after grit removal } \\
\text { and Canadian-type anaerobic } \\
\text { digestion) }\end{array}$ & $\begin{array}{c}\text { Raceway } \\
\text { (Working volume of 15 L) }\end{array}$ & Up to $300 \mathrm{mg}$ VSS/L & [52] \\
\hline $\begin{array}{l}\text { Swine manure (after pre-treatment to } \\
\text { reduce the total suspended solid } \\
\text { content by } 70 \% \text { ) diluted } 20-\text { and } \\
10 \text {-fold with tap water }\end{array}$ & $\begin{array}{c}\text { Raceway } \\
\text { (Working volume of } 464 \mathrm{~L} \text { with a surface } \\
\text { of } 1.54 \mathrm{~m}^{2}(2.3 \mathrm{~m} \text { long } \times 0.70 \mathrm{~m} \text { wide } \times \\
0.30 \mathrm{~m} \text { deep })\end{array}$ & $\begin{array}{l}\mathrm{Up} \text { to } 21.3 \text { and } 27.7 \mathrm{~g} / \mathrm{m}^{2} / \mathrm{d} \\
\text { (respectively) }\end{array}$ & [53] \\
\hline
\end{tabular}

TSS—-total suspended solids; TVS—-total volatile solids; VSS—volatile suspended solids.

The possibility of including microalgae culturing using microalgae-based systems for the treatment of the side stream flow of centrate from biosolid dewatering has been largely explored. Centrate has a high nitrogen concentration; thus, it cannot be directly 
discharged. Thus, this stream is usually sent back to the water line of the WWTP to be further treated, increasing the nitrogen load at the entrance of the biological processes in $20-30 \%$ [42]. The main aim of this process is to produce microalgae biomass that can be further used to feed the existent anaerobic digesters to increase biogas production and, in turn, improve the energy balance and the carbon footprint of the whole process. Additionally, the oxygen produced by microalgae will potentially reduce the aeration demand for nitrification in the water line. The microalgae biomass productivities found in the different pilot-scale studies using centrate streams were very variable, which is probably related to the environmental conditions and to the centrate composition or may even be due to the type of reactor used [42-47]. Nevertheless, in the long run, it seems to be a feasible integrated biorefinery process.

Owing to the microalgae biomass applications in diverse fields, there is a huge prospect for the development of sustainable processes where microalgal production can be accomplished using industrial wastewater. Kumar and colleagues [50] evaluated the techno-economic feasibility of a microalgae-based dairy effluent treatment for the simultaneous production of microalgae biomass and clean water. The high volume V-shaped pond used in this study seemed to be a cost effective and area efficient microalgal cultivation system, allowing an annual algal production of 504 ton at USD $0.482 / \mathrm{kg}$ along with a production of approximately $240,000 \mathrm{~m}^{3}$ of treated clean water. Recently, in a circular economy context, the potential of polishing of swine wastewater with microalgae along with the production of biomass with added value was explored [52]. At the beginning, the bacterial activity exceeded that of the photosynthesizing organisms, but in the long run, the proportion of photosynthesizing organisms in the total biomass substantially increased.

\subsection{Single Cell Protein}

The increasing demand for food supply, especially proteins, forced the search for new ways to obtain them. Recently, there is an increasing interest to obtain single cell proteins $(\mathrm{SCP})$ by recycling the organics and nutrients present in wastewater. Sewage sludge is a valuable source of proteins due to the high content of these components in the sludge composition (about $61 \%$ proteins, $11 \%$ carbohydrates, $1 \%$ lipids, and $27 \%$ other components) [54]. Taking in account that approximately $50 \%$ of the dry weight of the bacterial cells are proteins, the protein extract that can be recovered from sewage sludge is very promising. Nevertheless, apart from the bacterial cultures, the SCP can also be obtained from other types of biomasses such as microscopic algae, yeast or fungi [55]. Some examples of SCP production from different streams are shown in Table 5.

Table 5. Single cell protein production from different streams at pilot-scale.

\begin{tabular}{cccc}
\hline Waste Stream & Process & Culture & Productivity \\
\hline $\begin{array}{c}\text { Acidified stream from brewery } \\
\text { industry }\end{array}$ & $\begin{array}{c}\text { Aerobic with SRT < 8 days } \\
\text { and nutrient addition }\end{array}$ & $\begin{array}{c}\text { Enrichment of Alpha- } \\
\text { and Beta-proteobacteria }\end{array}$ & $\begin{array}{c}>55 \% \text { crude protein } \\
\text { content }\end{array}$ \\
\hline $\begin{array}{c}\text { Mixture composed of } \mathrm{CO}_{2} \text { and } \\
\mathrm{NH}_{3} \text { from sludge treatment } \\
\text { plant and } \mathrm{H}_{2} \text { and } \mathrm{O}_{2} \text { from } \\
\text { water electrolysis }\end{array}$ & $\begin{array}{c}\text { Autotrophic by hydrogen } \\
\text { using bacteria }\end{array}$ & $\mathrm{H}_{2}$-oxidizing bacteria & $\begin{array}{c}49-75 \% \text { crude protein } \\
\text { content } \\
1 \mathrm{~kg} \mathrm{SCP} / \mathrm{d}\end{array}$ \\
\hline $\begin{array}{c}\text { Domestic wastewater mixed } \\
\text { with organic fraction of } \\
\text { municipal solid waste }\end{array}$ & Anaerobic raceway & $\begin{array}{c}\text { Purple phototrophic } \\
\text { bacteria }\end{array}$ & n.r. \\
\hline
\end{tabular}

n.r.-not reported; SRT—sludge retention time.

Phototrophic organisms, such as microalgae or purple phototrophic bacteria, appear as the best solution because of their high carbon yields and high nutrient capture potentials [59]. In the research work of Hülsen and colleagues [60], the capacities of microalgae and purple phototrophic bacteria to treat different agro-industrial wastewaters and to produce SCP were compared. They concluded that the removal efficiencies (COD, Ni- 
trogen and Phosphorous) were better with microalgae than with purple phototrophic bacteria, but the latter had better SCP production ( $>50 \%$ protein content) than microalgae ( $<30 \%$ protein content). In fact, in the review of Capson-Tojo and colleagues [61], it is stated that the biomass yield of purple phototrophic bacteria can range between 0.5 and $1.0 \mathrm{~g}$ $\mathrm{COD} / \mathrm{g}$ COD removed, which indicates the high potential of this type of culture to obtain SCP. Technologies based on purple phototrophic bacteria are starting to be implemented at the pilot-scale, and there is still no available data for larger-setting applications.

Regarding legislation for the use of SCP obtained from waste, such as wastewater, the review from Hülsen and colleagues [55] states that there are several guidelines and regulations around the world with complex and case-dependent situations to commercialize this type of product. The different legislations differ between food for humans and for animals, and in this last category, between pets and livestock. There are also differences between food, feed additives, and medical feed. Therefore, the presence of pathogens, xenobiotics, metals, etc., which are present in most of the wastewater streams from municipal WWTPs, causes the production of SCP to be preferentially applied to wastewater streams generated by the food processing industries [55].

\section{Nutrients and Fertilizers}

Nutrient (Nitrogen and Phosphorous) recovery as soil fertilizers from wastewater can be a good alternative to avoid unregulated wastewater discharge while also solving the problem of poor access to chemical synthetized fertilizers, especially in developing countries, due to their high cost.

Phosphorous is a nonrenewable natural resource that is essential for the production of phosphorous-based fertilizers. The lack of this resource in the planet led to the development of biological and chemical processes to recover nutrients from wastewater and sludge [62,63]. In the review of Saliu and Oladoja [64], the authors stated the possibility of nutrient recovery from different kinds of nutrient-rich wastewater including that from agricultural practices and from industrial and municipal facilities. Additionally, the reviewed literature confirmed the viability of the recovered nutrients for reuse as fertilizer in agricultural practices, as their fertilizing effect is comparable with or is even better than commercial fertilizers. Some examples of nutrient recovery from wastewater as valuable products at full-scale are presented in Table 6.

Table 6. Nutrient and fertilizer recovery as valuable products from different kinds of wastewater at full-scale processes.

\begin{tabular}{|c|c|c|c|c|}
\hline Product & Process & Stream & Recovery & Reference \\
\hline Struvite & Crystallization & $\begin{array}{c}\text { Reject water from } \\
\text { sludge anaerobic } \\
\text { digester }(1.1-2.2 \mathrm{mmol} \\
\mathrm{PO}_{4}^{-3} / \mathrm{L} \text { and } 70 \mathrm{mmol} \\
\left.\mathrm{NH}_{4}^{+} / \mathrm{L}\right)\end{array}$ & $\begin{array}{l}\text { 77\% of the } \\
\text { Phosphorous } \\
\text { Pellets of } 0.5-5.0 \mathrm{~mm}\end{array}$ & {$[65]$} \\
\hline Ammonium sulphate & $\begin{array}{l}\text { Vacuum stripping using } \\
\text { gypsum and scrubbing }\end{array}$ & $\begin{array}{c}\text { Reject water from } \\
\text { sludge anaerobic } \\
\text { digester }(4.4 \mathrm{~g} \\
\left.\mathrm{NH}_{4}^{+}-\mathrm{N} / \mathrm{kg} \text { digestate }\right)\end{array}$ & $57 \%$ of Ammonium & {$[66]$} \\
\hline Ammonium sulphate & $\begin{array}{l}\text { Pre-treatment with caustic } \\
\text { soda, lamella clarification, } \\
\text { filtration, and three-stage } \\
\text { membrane contactor with } \\
\text { sulphuric acid addition }\end{array}$ & $\begin{array}{l}\text { Reject water from } \\
\text { sludge anaerobic } \\
\text { digester }(1000 \mathrm{mg} \\
\left.\mathrm{NH}_{4}^{+}-\mathrm{N} / \mathrm{L}\right)\end{array}$ & $\begin{array}{l}96 \% \text { of Nitrogen } \\
\text { removal efficiency and } \\
4.1 \% \text { of Nitrogen in the } \\
\left(\mathrm{NH}_{4}\right)_{2} \mathrm{SO}_{4} \text { produced }\end{array}$ & [67] \\
\hline
\end{tabular}


Considering the high cost of ammonium removal in conventional WWTPs by nitrification-denitrification processes and of ammonium-based fertilizer production by the HaberBosch process, the recovery of such compound seems more valuable than its removal. However, ammonium recovery is only economically feasible when applied to large WWTPs that are able to produce large concentrations of such ions [68]. The ammonium concentration in wastewater sources varies depending on the origin. For example, in municipal WWTPs, the mainstream line contains around $100 \mathrm{mg}$ of nitrogen per litre, while the reject water from anaerobic sludge digesters has around $1000 \mathrm{mg}$ of nitrogen per litre. According to Ye and colleagues [68], there are three main ammonium recovery mechanisms: struvite precipitation, ammonia stripping coupled with adsorption, and membrane concentration. The struvite precipitation is more advantageous as, apart from ammonium, it simultaneously recovers phosphate. The struvite (magnesium ammonium phosphate hexahydrate) is often preferable over mineral phosphorous fertilizers, as it is less soluble in water, and when applied to soils, it allows the slow release of phosphorous, which is more beneficial for plant growth [69]. Recovery by means of the stripping-adsorption mechanisms need the application of high temperatures and/or $\mathrm{pH}$ values, and the stripped ammonia is adsorbed by acid solutions to form ammonium salts such as ammonium sulphate. Alternatively, through the membrane concentration, ammonium enrichment can be accomplished, separating it from the other co-existent substances. In this case, the membrane technology involved can be forward osmosis, reverse osmosis, membrane distillation, and electrodialysis.

Regarding the phosphorous present in wastewater, about $95 \%$ is transferred to the sludge in WWTPs. Phosphorous can be recovered in multiple sections of a WWTP through three main paths: from the liquid phase (i.e., in aqueous phase from digester supernatant, as dissolved phosphorous in anaerobically digested sludge, and in the effluent), from sewage sludge (direct agricultural utilization), and from sewage sludge incineration ashes [70]. Therefore, to date, various technologies have been applied for phosphorous recovery at pilot- and full-scale levels in WWTPs, namely the REM-NUT ${ }^{\circledR}$ (ion exchange and precipitation in the secondary treated effluent), AirPrex ${ }^{\circledR}$ (precipitation/crystallization of dissolved phosphorous contained in the anaerobically digested sludge), Ostara-Pearl-Reactor ${ }^{\circledR}$, DHV Crystalactor $^{\circledR}, \mathrm{P}-R o C^{\circledR}$, PRISA $^{\circledR}$ (all these technologies are based on crystallization of phosphorous in digester supernatant), Gifhorn and Stuttgart processes ${ }^{\circledR}$ (wet chemical leaching from digested sludge), PHOXNAN ${ }^{\circledR}$ (wet oxidation of thickened sludge), Aqua Reci ${ }^{\circledR}$ (super critical water oxidation of thickened sludge), MEPHREC $^{\circledR}$ (metallurgic melt-gassing of dewatered sludge), AshDec ${ }^{\circledR}$ depollution (thermo-chemical depollution of sludge ash), AshDec ${ }^{\circledR}$ Rhenania (thermo-chemical phosphorous recovery from sludge ash), $\mathrm{PASCH}^{\circledR}$, LEACHPHOS $^{\circledR}$, EcoPhos $^{\circledR}$ (acidic wet-chemical leaching of sludge ash), RecoPhos ${ }^{\circledR}$, Fertilizer Industry ${ }^{\circledR}$ (acidic wet-chemical extraction of sludge ash), and Thermophos $\left(\mathrm{P}_{4}\right)^{\circledR}$ (thermo-electrical phosphorous extraction) [70]. However, a critical issue with phosphorous recovery processes is mainly related to the presence of metals (e.g., $\mathrm{Zn}, \mathrm{Cu}, \mathrm{Cd}$ ) in the final products. The removal of metals from the final product is strictly dependent on the local regulatory requirements, and it is mandatory in the case of fertilizer production. This obviously affects the phosphorous recovery costs [70].

In Europe, wastewater nutrient recovery as fertilizers had not a dedicated legislation until 2019, when the Fertilizing Products Regulation 2019/1009 was published. This regulation states that the impurities in European Union fertilizing products derived from biowaste, particularly from metals such as cadmium, should be either prevented or limited.

In the United States, the use of sewage or sewage sludge as fertilizer in agriculture is regulated under the Clean Water Act and, more specifically, in the 40 Code of Federal Regulations Part 503 "Standards for the Use or Disposal of Sewage Sludge" [71]. These regulations stablish general requirements, pollutant limits (specially for metals), management practices, and operational standards for the final use or disposal of sewage sludge. 


\section{Energy}

The nexus between water and energy is one of the crucial elements for sustainable development. As WWTPs consume large amounts of energy, research efforts are underway to develop technologies for its recovery and to convert WWTPs from energy consumers to energy producers. The types of energy that can be obtained from sewage include biogas from anaerobic digestion (the most common), electrical energy (from bioelectrochemical treatment processes), low-head hydroelectric energy, renewable fuels from sludge processing, and heat energy [72].

Anaerobic digestion consists of the degradation of complex organic matter that is converted into biogas, such as methane and carbon dioxide, which can then be energetically revalorized. Traditionally, anaerobic digestion is performed by a synergic microbial consortium in four sequential steps (hydrolysis, acidogenesis, acetogenesis, and methanogenesis), where the products resulting from one stage are then used as substrate for the following stages and ending up in biogas production [73].

Conventional WWTPs commonly include activated sludge treatment to treat the incoming wastewater plus the anaerobic digestion process for the surplus sludge that is produced, which are well established processes in WWTPs from many countries [74]. Anaerobic digestion is therefore one of the most commonly applied bioprocesses for recovering energy from sewage sludge (Table 7).

Nevertheless, it is also applied to recover energy directly from industrial and municipal wastewater; the latter is mainly the case in countries with warm temperatures, such as Brazil [75].

A major drawback in recovering energy from sewage sludge is related to the low biodegradability of the sludge produced in urban WWTPs, which often leads to low biogas (methane) yields. Therefore, the anaerobic co-digestion of wastewater surplus sludge and other biomass wastes has thus emerged as a viable alternative to increase biogas production. The co-digestion of sludge and food waste has been explored, as it contributes to the circular economy concept: products at the end of their life service or waste materials are turned into resources for another valuable purpose, thus closing loops in industrial ecosystems and minimizing waste [76].

Table 7. Energy recovery as biogas in anaerobic digestion processes using different feedstocks.

\begin{tabular}{|c|c|c|c|c|}
\hline Feedstock & Scale & Type of Reactor & $\begin{array}{l}\text { Biogas } \\
\text { Productivity }\end{array}$ & Reference \\
\hline $\begin{array}{l}\text { Microalgae biomass plus } \\
\text { primary sludge waste }\end{array}$ & Pilot-scale & $\begin{array}{l}\text { Anaerobic membrane } \\
\text { bioreactor }\end{array}$ & $370 \mathrm{~mL} \mathrm{CH}_{4} / \mathrm{g} \mathrm{VS}_{\text {influent }}$ & [77] \\
\hline $\begin{array}{l}\text { Waste activated sludge } \\
\text { plus organic fraction of } \\
\text { municipal solid waste }\end{array}$ & Full-scale & $\begin{array}{c}\text { Pre-thickener plus a } \\
\text { digester }\end{array}$ & up to $0.43 \mathrm{~m}^{3} / \mathrm{kg}$ TVS $/ \mathrm{d}$ & [78] \\
\hline $\begin{array}{l}\text { Sewage sludge plus } \\
\text { crude glycerol }\end{array}$ & Pilot-scale & $\begin{array}{c}\text { Continuous stirred tank } \\
\text { reactor }\end{array}$ & $0.87 \mathrm{LCH}_{4} / \mathrm{g} \mathrm{VS}$ & [79] \\
\hline $\begin{array}{c}\text { Sewage sludge plus } \\
\text { agro-industrial } \\
\text { by-product (olive mill } \\
\text { wastewater, crude } \\
\text { glycerol, or cheese whey) } \\
(95 / 5, v / v) .\end{array}$ & Pilot-scale & Anaerobic digester & $\begin{array}{l}34.8 \pm 3.2,185.7 \pm 15.3 \text { and } \\
45.9 \pm 3.6 \mathrm{~L} / \mathrm{d}, \text { respectively }\end{array}$ & [80] \\
\hline $\begin{array}{l}\text { Screenings generated } \\
\text { from the operations of } \\
\text { pre-treatment of } \\
\text { municipal wastewater }\end{array}$ & Pilot-scale & $\begin{array}{c}\text { Mechanical stirring } \\
\text { cylindrical digester } \\
\text { (working volume of } 50 \mathrm{~L} \text { ) }\end{array}$ & $653 \mathrm{Nl} / \mathrm{kg}$ VS per week & [81] \\
\hline
\end{tabular}


Table 7. Cont.

\begin{tabular}{ccccc}
\hline Feedstock & Scale & Type of Reactor & $\begin{array}{c}\text { Biogas } \\
\text { Productivity }\end{array}$ & Reference \\
\hline $\begin{array}{c}\text { Sewage sludge plus } \\
\text { different beverage wastes } \\
\text { (namely beer, soft drinks, } \\
\text { fruit juice, or wine) }\end{array}$ & Pilot-scale & $\begin{array}{c}\text { Anaerobic conical stainless } \\
\text { steel reactor }\end{array}$ & $\begin{array}{c}\text { Up to 237 L CH} / \mathrm{kg} \\
\text { COD added }\end{array}$ \\
\hline Municipal wastewater & Pilot-scale & $\begin{array}{c}\text { Anaerobic membrane } \\
\text { bioreactor }\end{array}$ & 0.09-0.29 L CH $/ \mathrm{g} \mathrm{COD}^{\text {[82] }}$ \\
\hline $\begin{array}{c}\text { Filtrate resulting of } \\
\text { sludge dewatering }\end{array}$ & Pilot-scale & $\begin{array}{c}\text { Upflow anaerobic sludge } \\
\text { blanket reactor }\end{array}$ & $260 \mathrm{~mL} / \mathrm{g} \mathrm{COD}$ \\
\hline
\end{tabular}

VS-volatile solids; TVS—-total volatile solids.

Recently, Li and colleagues [83] explored an integrated process to valorize sewage sludge, aiming at its full use, in a process combining hydrothermal pretreatment, anaerobic digestion, and pyrolysis. This pilot-scale study showed that the hydrothermal pretreatment of sewage sludge improved the dewaterability of the sludge, generating a filter cake with a solid content of $67 \% \mathrm{wt}$ while the continuous anaerobic digestion of the resulting filtrate presented a methane yield of $260 \mathrm{~mL} / \mathrm{g} \mathrm{COD}$, a quantity of biogas that is able to compensate for the energy required for the former process. Meanwhile, the filter cake was pyrolyzed to generate biochar.

Microalgae-based systems are being largely adopted in full-scale WWTPs, and the potential of microalgae biomass as feedstock for biofuels is very appealing due to their higher heating values and rapid growth rate. Microalgae gasification using compact microgeneration systems was successfully explored at pilot-scale as an alternative for the microgeneration of energy in WWTPs [84]. A commercial downdraft gasifier was used, and the best performance obtained a syngas production rate of $2.8 \mathrm{Nm}^{3} / \mathrm{kg}$ biomass dry, with a syngas composition of $11.9 \% \mathrm{H}_{2}, 19.5 \% \mathrm{CO}, 8.5 \% \mathrm{C}_{\mathrm{x}} \mathrm{H}_{\mathrm{y}}$ and $9.8 \% \mathrm{CO}_{2}$.

Another promising alternative for energy generation are microbial fuel cells (MFC). In this case, the organic load present in the wastewater is converted into electrical energy by bacteria. The MFC are a very promising technology, but its scale up has faced some challenges due to the complexity of the installation and operating procedures as well as other engineering and environmental factors [85]. One of the main problems is that power generation decreases with the increase of the reactor size. Miniaturization of the MFC and the connection of multiple MFC units in stack configurations were adopted strategies that allowed for increased power densities. Perhaps these challenges hindered the investigation of large-scale prototypes, as it has only been more recently that pilot studies have been conducted (Table 8). Most of these pilot studies explored the use of stackable or tubular units to multiply MFC components. By connecting those multiple small-sized units, power generation can be largely increased, thus contributing to the technology applicability to meet the criteria for high performance in real-world conditions.

Table 8. Configuration and performances of microbial fuel cells operation at pilot-scale.

\begin{tabular}{|c|c|c|c|c|}
\hline Feedstock & Type of Reactor & Power Density Produced & Net Energy Recovered & Reference \\
\hline $\begin{array}{l}\text { Effluent of the primary } \\
\text { clarifier of a WWTP }\end{array}$ & $\begin{array}{l}\text { Four single-chamber } \\
\text { membraneless MFCs } \\
\text { (total volume of } 45 \mathrm{~L} \text { ) }\end{array}$ & $\mathrm{Up}$ to $82 \pm 18 \mathrm{~mW} / \mathrm{m}^{2}$ & $\begin{array}{c}\text { Up to } \\
0.025 \pm 0.013 \mathrm{kWh} / \mathrm{m}^{3}\end{array}$ & [86] \\
\hline $\begin{array}{l}\text { Synthetic wastewater } \\
\text { with variable influent } \\
\text { COD concentrations } \\
(200-800 \mathrm{mg} / \mathrm{L})\end{array}$ & $\begin{array}{c}\text { Five stacked MFC } \\
\text { units(total volume of } 72 \mathrm{~L} \text { ) }\end{array}$ & $\begin{array}{l}\text { Up to } 50.9 \text { and } 42.1 \mathrm{~W} / \mathrm{m}^{3} \\
\text { in fed-batch and } \\
\text { continuous, respectively }\end{array}$ & n.r. & [87] \\
\hline
\end{tabular}


Table 8. Cont.

\begin{tabular}{ccccc}
\hline Feedstock & Type of Reactor & Power Density Produced & Net Energy Recovered & Reference \\
\hline $\begin{array}{c}\text { Domestic wastewater } \\
\text { from a WWTP }\end{array}$ & Single-chamber MFC unit & Up to $175.9 \mathrm{~mW} / \mathrm{m}^{2}$ & n.r. & [88] \\
\hline Brewery wastewater & $\begin{array}{c}\text { Five stacked MFC } \\
\text { units (total volume of } 90 \mathrm{~L})\end{array}$ & Up to $181 \pm 21 \mathrm{~mW} / \mathrm{m}^{2}$ & $0.097 \mathrm{kWh} / \mathrm{m}^{3}$ & {$[89]$} \\
\hline $\begin{array}{c}\text { Municipal wastewater } \\
\text { from a WWTP }\end{array}$ & $\begin{array}{c}50 \text { stacked MFC units } \\
\text { (total volume of } 1000 \mathrm{~L})\end{array}$ & $\begin{array}{c}\text { Up to } 3.64 \mathrm{~W} / \mathrm{m}^{2} \\
\left(\sim 60 \mathrm{~W} / \mathrm{m}^{3}\right)\end{array}$ & $0.033 \pm 0.005 \mathrm{kWh} / \mathrm{m}^{3}$ \\
\hline
\end{tabular}

n.r.-not reported.

The possibility of using wastewater as an alternative source of energy for heating has recently emerged as a feasible approach. Cecconet and colleagues [72] designed a system with heat exchangers and pumps where the energy contained in the wastewater was recovered for heating and cooling a building with a calculated energy requirement of $957 \mathrm{MWh}$ per year, which allowed for a reduction of $59 \%$ of this value.

\section{Volatile Fatty Acids}

The volatile fatty acids (VFAs) are valuable compounds with a high market demand and with several applications, namely as precursors for bioplastics (e.g., polyhydroxyalkanoates (PHA)), biogas, biohydrogen, and biodiesel production as well as for nutrient removal (Figure 3) [91,92].

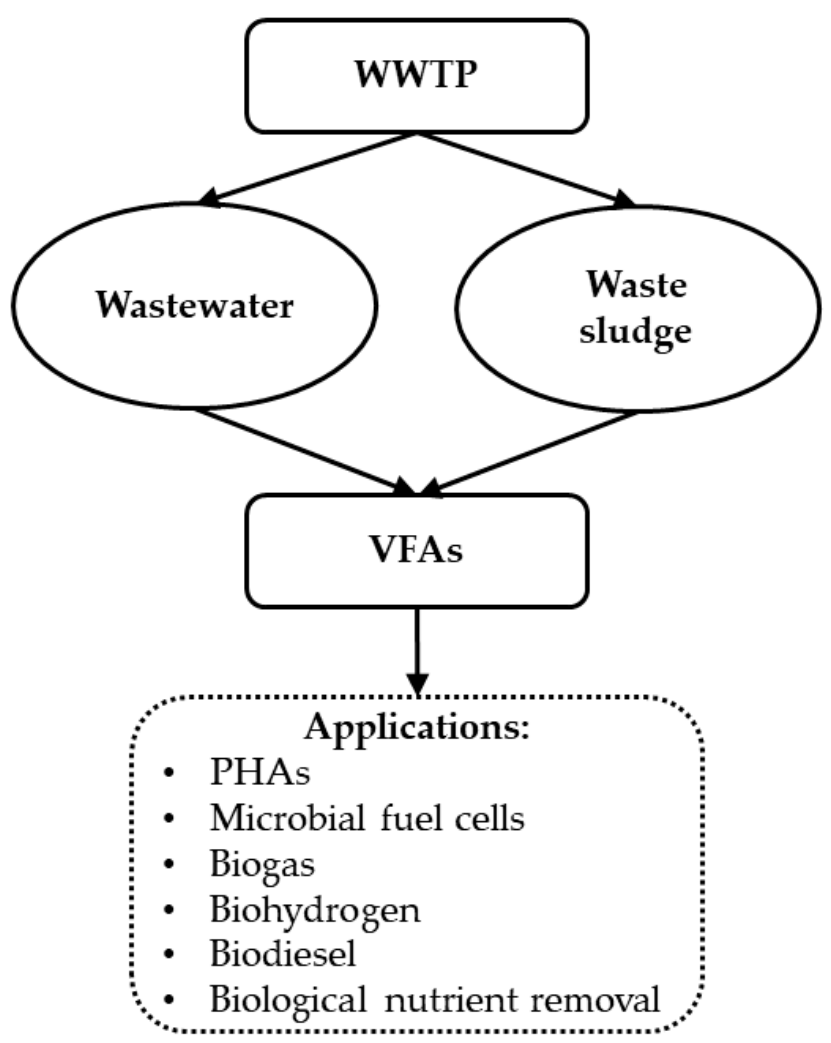

Figure 3. Biorefinery concept overview: volatile fatty acids production and their applications.

VFAs also have high industrial interest as chemical building blocks, such as for use as plasticizers, food additives, dyes, resins, pharmaceuticals, and paints. VFAs are short-chain fatty acids with a low molecular weight that consist of two to six carbon atoms and that are mostly derived from fossil fuels using chemical routes, leading to serious negative health and environmental impacts $[93,94]$. Thus, the replacement of these processes by biological 
ones such as by using pure or mixed microbial cultures or by using renewable carbon sources is gaining more attention $[91,92,94,95]$. This strategy represents a cost-effective and environmentally friendly alternative for VFAs production [91]. The use of pure cultures for VFA production has been studied extensively [91]. However, such processes use refined carbon sources and must occur under sterile conditions, leading to high operating costs. Thus, research on mixed microbial cultures is emerging [91,94-96]. Mixed microbial cultures can use organic waste as carbon source, such as sewage or sewage sludge, with the added advantage that they do not need sterile conditions to operate. This presents several advantages, namely decreasing generated waste and contributing to environmental sustainability and to a circular economy.

The conversion of the organic content of waste feedstock into VFAs by mixed microbial cultures involves an acidogenic fermentation process [97]. This is an anaerobic process that involves both hydrolysis and acidogenesis. In hydrolysis, complex organic polymers (such as proteins, cellulose, lignin, and lipids) are broken down into simpler soluble monomers (such as amino acids, simple sugars, glycerol, and fatty acids) by the enzymes excreted by hydrolytic microorganisms. Then, these monomers are converted into VFAs (acidogenesis) by fermentative acidogenic bacteria. In an anaerobic reactor, both processes occur simultaneously, with hydrolysis generally being considered the rate-limiting step. To avoid the consumption of VFAs for biogas production by methanogens, a high $\mathrm{pH}$ (above 8) or low $\mathrm{pH}$ (below 6) is generally used [95,98-100]. Moreover, to maximize VFA production yield and to control the composition of the synthesized VFAs, operating parameters such as hydraulic retention time (HRT), sludge retention time (SRT), organic loading rate (OLR), $\mathrm{pH}$, temperature, and reactor configuration must be optimized.

Although most of the studies on VFA production using biological routes are at labscale, some pilot- and full-scale studies with promising results can be found in the literature and are summarized in Table 9.

Even though specific regulations on the application and commercialization of VFAs derived from waste and wastewater is lacking, Directive 2008/98/EC of the European Parliament and of the Council of 19 November 2008 states measures for the handling and management of waste [38]. This Directive encourages the use of environmentally safe materials produced from biowaste, which may include VFAs produced from waste and wastewater. In the near future, legislation regulating the products from the valorization of waste and wastewater will certainly appear as a response to the need for sustainable alternatives.

Table 9. VFAs produced at pilot- and full-scale.

\begin{tabular}{|c|c|c|c|c|c|c|c|c|}
\hline \multirow{2}{*}{$\begin{array}{l}\text { Waste } \\
\text { Stream }\end{array}$} & \multirow{2}{*}{ Scale } & \multirow{2}{*}{$\begin{array}{l}\text { Operating } \\
\text { Conditions }\end{array}$} & \multirow{2}{*}{ VFA Production } & \multicolumn{4}{|c|}{ VFA Composition (\%) } & \multirow{2}{*}{ Reference } \\
\hline & & & & Acetic Acid & Propionic Acid & Butyric Acid & Others & \\
\hline \multirow{3}{*}{ Primary sludge } & \multirow{3}{*}{ Pilot scale } & $\begin{array}{c}\text { Sequencing batch } \\
\text { fermentation } \\
\text { reactor- } 2.6 \mathrm{~m}^{3} \\
\mathrm{pH} 6 ; \mathrm{HRT} 6 \text { days, } \\
37^{\circ} \mathrm{C}\end{array}$ & $\begin{array}{c}154 \pm 24 \mathrm{mg} \\
\mathrm{COD} / \mathrm{g} \mathrm{VS} \\
1.23 \mathrm{Kg} \\
\mathrm{COD} / \mathrm{m}^{3} \text { reactor } \mathrm{d}\end{array}$ & 30 & 45 & - & & \multirow{3}{*}{ [101] } \\
\hline & & $\begin{array}{l}\text { Sequencing batch } \\
\text { fermentation } \\
\text { reactor-2.6 m } \\
\text { pH 6; HRT } 14 \text { days, } \\
37^{\circ} \mathrm{C}\end{array}$ & $\begin{array}{c}137 \pm 33 \mathrm{mg} \\
\mathrm{COD} / \mathrm{g} \mathrm{VS} \\
0.44 \mathrm{Kg} \\
\mathrm{COD} / \mathrm{m}^{3} \text { reactor } \mathrm{d}\end{array}$ & 25 & 53 & - & & \\
\hline & & $\begin{array}{c}\text { Sequencing batch } \\
\text { fermentation } \\
\text { reactor- } 2.6 \mathrm{~m}^{3} \\
\text { pH 9; HRT } 6 \text { days, } \\
37^{\circ} \mathrm{C}\end{array}$ & $\begin{array}{c}322 \pm 56 \mathrm{mg} \\
\mathrm{COD} / \mathrm{g} \mathrm{VS} \\
2.57 \mathrm{Kg} \\
\mathrm{COD} / \mathrm{m}^{3} \text { reactor } \mathrm{d}\end{array}$ & 29 & 51 & - & & \\
\hline
\end{tabular}


Table 9. Cont.

\begin{tabular}{|c|c|c|c|c|c|c|c|c|}
\hline \multirow{2}{*}{$\begin{array}{l}\text { Waste } \\
\text { Stream }\end{array}$} & \multirow{2}{*}{ Scale } & \multirow{2}{*}{$\begin{array}{l}\text { Operating } \\
\text { Conditions }\end{array}$} & \multirow{2}{*}{ VFA Production } & \multicolumn{4}{|c|}{ VFA Composition (\%) } & \multirow{2}{*}{ Reference } \\
\hline & & & & Acetic Acid & Propionic Acid & Butyric Acid & Others & \\
\hline \multirow{5}{*}{ Sewage sludge } & \multirow{5}{*}{ Pilot scale } & $\begin{array}{l}\text { Stirred reactor } \\
\text { coupled to a } \\
\text { membrane } \\
\text { separation system } \\
\text { pH 5.7; HRT 5 days; } \\
\text { SRT } 14 \text { days; } 35^{\circ} \mathrm{C}\end{array}$ & $\begin{array}{c}206.5 \mathrm{mg} \mathrm{COD} / \mathrm{g} \\
\text { TVS } \\
3389 \pm 1320 \mathrm{mg} \\
\text { COD } / \mathrm{L}\end{array}$ & 31 & 28 & 23 & & \multirow{5}{*}{ [102] } \\
\hline & & $\begin{array}{l}\text { Stirred reactor } \\
\text { coupled to a } \\
\text { membrane } \\
\text { separation system } \\
\text { pH 10; HRT } 6 \text { days; } \\
\text { SRT } 14 \text { days; } 35^{\circ} \mathrm{C}\end{array}$ & $\begin{array}{c}315.6 \mathrm{mg} \mathrm{COD} / \mathrm{g} \\
\text { TVS } \\
7453 \pm 1092 \mathrm{mg} \\
\text { COD } / \mathrm{L}\end{array}$ & 40 & 24 & 17 & & \\
\hline & & $\begin{array}{c}\text { Stirred reactor } \\
\text { coupled to a } \\
\text { membrane } \\
\text { separation system } \\
\text { pH 7; HRT } 5 \text { days; } \\
\text { SRT } 14 \text { days; } 35^{\circ} \mathrm{C}\end{array}$ & $\begin{array}{c}227.9 \mathrm{mg} \mathrm{COD} / \mathrm{g} \\
\text { TVS } \\
5596 \pm 448 \mathrm{mg} \\
\text { COD } / \mathrm{L}\end{array}$ & 42 & 30 & 15 & & \\
\hline & & $\begin{array}{l}\text { Stirred reactor } \\
\text { coupled to a } \\
\text { membrane } \\
\text { separation system } \\
\text { pH 7; HRT } 5 \text { days; } \\
\text { SRT } 6 \text { days; } 35^{\circ} \mathrm{C}\end{array}$ & $\begin{array}{c}248.6 \mathrm{mg} \mathrm{COD} / \mathrm{g} \\
\text { TVS } \\
3738 \pm 411 \mathrm{mg} \\
\text { COD } / \mathrm{L}\end{array}$ & 42 & 30 & 16 & & \\
\hline & & $\begin{array}{l}\text { Stirred reactor } \\
\text { coupled to a } \\
\text { membrane } \\
\text { separation system } \\
\text { pH 10; HRT } 5 \text { days; } \\
\text { SRT } 5 \text { days; } 35^{\circ} \mathrm{C}\end{array}$ & $\begin{array}{c}325.0 \mathrm{mg} \mathrm{COD} / \mathrm{g} \\
\text { TVS } \\
3184 \pm 219 \mathrm{mg} \\
\text { COD } / \mathrm{L}\end{array}$ & 50 & 16 & 10 & & \\
\hline Sewage sludge & Full scale & $\begin{array}{c}\text { Stirred tank } \\
\text { reactor-30 m }{ }^{3} \\
\text { pH } 10-11 ; 35^{\circ} \mathrm{C}\end{array}$ & 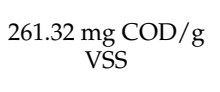 & 58 & 7 & - & 35 & [103] \\
\hline
\end{tabular}

HRT—hydraulic retention time; SRT—sludge retention time; VS—volatile solids; TVS—-total volatile solids; VSS—volatile suspended solids.

\section{Polyhydroxyalkanoates}

Polyhydroxyalkanoates (PHAs), a family of polyesters that are naturally produced by bacteria as energy and carbon storage materials, are an alternative to conventional fossil-based plastics, and their production and accumulation in the planet are harmful to the environment and human health [104]. These bioplastics are biodegradable and biocompatible, can be produced from renewable resources, and have similar properties to petrochemical polymers, namely propylene $[97,105,106]$. Due to their biocompatibility, biodegradability, and green credentials, PHAs are being extensively applied in many fields, namely in the medical sector (e.g., tissue engineering, bio-implant patches, drug delivery, surgical applications, medical devices) and in nanotechnology (e.g., biocomposites for applications in various industrial sectors, such as in packaging, agriculture, automotive industry, and building) [107-109].

Industrial processes for PHA production are currently based on pure cultures and pure substrates (e.g., Biomer-Germany, Tianan-China). Making this process more cost effective and competitive, low cost processes for PHA production, such as using mixed microbial cultures, have been developed [110,111]. The use of mixed microbial cultures instead of pure cultures allows for the reduction of PHA production costs, and since no sterilization is necessary, few process controls are required, and cheap or even free substrates such as industrial waste or by-products can be used as feedstock since the microbial population can continuously adapt to changes in the substrate [97,112-117]. Municipal wastewater sludge can be a sustainable alternative as it is a raw material that can be used to produce bioplastics, namely as a substrate or as a source of PHA accumulating microorganisms [118].

PHA production processes involving mixed microbial cultures commonly operate in 3-stages [97]: (1) the acidogenic fermentation stage, (2) the culture selection stage, and (3) the PHA production stage. The acidogenic fermentation process enables the conversion of the organic content of waste feedstock into VFAs, which are the preferred substrates 
for PHA production [97]. Control of the produced VFAs is extremely important since it will influence final polymer composition and, consequently, affect its thermomechanical properties $[97,113,119]$.

In the culture selection stage (second stage), the mixed microbial cultures are subjected to alternate periods of substrate excess (feast) and limitation (famine) in a process known as Aerobic Dynamic Feeding or the feast and famine regime, which allows the enrichment in organisms with high and stable PHA storage capacity. It is considered that the transient external substrate availability is responsible for creating an internal growth limitation that will promote the PHA storage capacity of the mixed microbial cultures. Additionally, the second aim of this stage is the production of a culture with high biomass volumetric productivity (high growth rate) without the impairment of high storage capacity for the accumulation stage. However, unlike pure cultures, this is still a challenge $[97,120]$.

In the PHA production stage (third stage), the selected mixed microbial cultures from the second stage are fed with the VFAs produced in the acidogenic fermentation stage, aiming to achieve the maximum PHA production capacity of the cultures. Even though PHA production from waste streams has been successfully applied at lab-scale, PHA recovery is still a costly step in the mixed microbial cultures process. Thus, it is still a challenge for the PHA production process up-scaling using mixed microbial cultures to become economically feasible $[121,122]$. However, some PHA producing pilot-scale plants based on the use of mixed microbial cultures and wastewater as a substrate can be found in the literature and are listed in Table 10.

The Veolia Group, the global leader in optimized resource management, is now working on the development of full-scale industrial PHA production from domestic wastewater, and a pilot plant is already in operation in Belgium [123].

Table 10. PHA production using mixed microbial cultures at pilot-scale.

\begin{tabular}{|c|c|c|c|c|}
\hline Waste Stream & $\begin{array}{l}\text { Operational } \\
\text { Conditions }\end{array}$ & PHA Production & $\begin{array}{c}\text { Polymer } \\
\text { Produced }\end{array}$ & Reference \\
\hline $\begin{array}{l}\text { Milk and ice-cream } \\
\text { wastewater }\end{array}$ & $\begin{array}{c}\mathrm{HRT}=\text { SRT } 43.56 \mathrm{~h} ; \\
\text { pH } 7.1\end{array}$ & $0.25 \mathrm{Kg}$ PHA $/ \mathrm{Kg}$ COD degraded & PHA & [124] \\
\hline $\begin{array}{l}\text { Municipal wastewater and } \\
\text { waste activated sludge }\end{array}$ & $\begin{array}{c}\mathrm{V} \text { reactor }=550 \mathrm{~L} ; \mathrm{OLR}=3.0 \mathrm{~g} \\
\mathrm{COD} / \mathrm{L} / \mathrm{d} ; \mathrm{HRT}=3 \mathrm{~h} ;\end{array}$ & $\begin{array}{c}0.25-0.38 \text { g COD-PHA/g COD } \\
\text { substrate } 0.27-0.38 \text { g PHA/g VSS }\end{array}$ & Poly-(3HB-co-3HV) & [125] \\
\hline Paper mill wastewater & $\begin{array}{c}\text { V reactor }=200 \mathrm{~L} \\
\mathrm{pH} 6.6 \\
\mathrm{~T}=30 \pm 2{ }^{\circ} \mathrm{C}\end{array}$ & $0.70-0.80$ g PHA/g VSS & PHA & [126] \\
\hline Municipal wastewater & $\begin{array}{c}\mathrm{V} \text { reactor }=511 \mathrm{~L} \\
\mathrm{SRT}=0.28-0.56 \text { days } \\
\mathrm{HRT}=30-60 \mathrm{~min} \\
\mathrm{DO}=0.5-1.5 \mathrm{mg} / \mathrm{L}\end{array}$ & 26.3-51.4 mg COD-PHA/g VSS & PHB, PHV & [127] \\
\hline $\begin{array}{l}\text { Olive mill wastewater } \\
\text { (OMW) }\end{array}$ & $\begin{array}{c}\text { V reactor }=30 \mathrm{~L} \\
\mathrm{~T}=27 \pm 2{ }^{\circ} \mathrm{C}\end{array}$ & $\begin{array}{c}24.60 \pm 0.21 \mathrm{~g} \text { PHA } / 100 \mathrm{~g} \\
\text { VSS7.58 g PHA } / \mathrm{L}_{\text {initial OMW }}\end{array}$ & $\begin{array}{l}\text { P3HB, P3HO or } \\
\text { 3-HB-co-3-HO }\end{array}$ & [128] \\
\hline $\begin{array}{c}\text { Excess sludge } \\
\text { fermentation liquid }\end{array}$ & $\begin{array}{c}\text { V reactor }=70 \mathrm{~L} \\
\mathrm{~T}=30^{\circ} \mathrm{C} \\
\mathrm{DO}>80 \% \mathrm{pH} \text { not controlled }\end{array}$ & $\begin{array}{l}0.17 \mathrm{~g} \text { PHA/g COD } \\
6.497 \mathrm{mg} \mathrm{PHA} / \mathrm{L} / \mathrm{h}\end{array}$ & PHA & [129] \\
\hline $\begin{array}{l}\text { Candy bar factory } \\
\text { wastewater }\end{array}$ & $\begin{array}{c}\text { V reactor }=200 \mathrm{~L} \\
\mathrm{~T}=30 \pm 2{ }^{\circ} \mathrm{C}\end{array}$ & $\begin{array}{c}0.76 \mathrm{~g} \text { PHA/g VSS } \\
0.30 \pm 0.04 \mathrm{~g} \text { COD-PHA/g COD }\end{array}$ & PHB, PHV & [130] \\
\hline $\begin{array}{c}\text { Municipal } \\
\text { wastewater-anaerobic } \\
\text { reject water }\end{array}$ & $\mathrm{V}$ reactor $=1 \mathrm{~m}^{3}$ & $\begin{array}{c}0.40-0.44 \mathrm{~g} \text { PHA } / \mathrm{g} \text { VSS } \\
0.58-0.61 \mathrm{~g} \text { COD-PHA } / \mathrm{g} \\
\text { COD-VFA } \\
224-234 \mathrm{mg} \text { PHA } / \mathrm{L} / \mathrm{h}\end{array}$ & PHB, PHV & [131] \\
\hline $\begin{array}{l}\text { Combined organic fraction } \\
\text { of municipal solid waste } \\
\text { and sewage sludge }\end{array}$ & $\begin{array}{l}\text { V reactor }=50-70 \mathrm{~L} \\
\mathrm{~T}=22-25^{\circ} \mathrm{C} \\
\mathrm{pH}=8.0-9.0\end{array}$ & $\begin{array}{c}0.43-0.46 \mathrm{~g} \text { PHA } / \mathrm{g} \text { VSS } \\
0.44-0.50 \mathrm{~g} \text { COD-PHA } / \mathrm{g} \\
\text { COD-VFA } \\
0.29-0.36 \mathrm{~g} \mathrm{PHA} / \mathrm{L} / \mathrm{h}\end{array}$ & PHB, PHV & [132] \\
\hline
\end{tabular}


Table 10. Cont.

\begin{tabular}{|c|c|c|c|c|}
\hline Waste Stream & $\begin{array}{l}\text { Operational } \\
\text { Conditions }\end{array}$ & PHA Production & $\begin{array}{l}\text { Polymer } \\
\text { Produced }\end{array}$ & Reference \\
\hline $\begin{array}{l}\text { Activated sludge } \\
\text { harvested from full scale } \\
\text { municipal wastewater } \\
\text { treatment-PHARIO }\end{array}$ & $\begin{array}{c}\text { V reactor }=500 \mathrm{~L} \\
\mathrm{~T}=25^{\circ} \mathrm{C}\end{array}$ & $\begin{array}{c}0.41 \mathrm{~g} \text { PHA /g VSS } \\
0.40-0.45 \text { g COD-PHA/g } \\
\text { COD-substrate consumed }\end{array}$ & PHB, PHV & [133] \\
\hline
\end{tabular}

There are still some constraints in the commercial use of PHAs derived from waste due to a lack of legislation. Recently PHAs were not considered to be natural polymers and thus were not considered suitable for single-use plastic products (Directive (EU) 2019/904 of the European Parliament and of the Council of 5 June 2019 on the reduction of the impact of certain plastic products on the environment) [134]. This has led to some discussion, as PHA producers and researchers disagree with this definition and claim that this European Union Directive guideline can compromise PHA potential as a sustainable alternative to single use fossil-fuel derived plastics in the European Union (GO!PHAGlobal Organization for PHA). However, it is expected that new legislation on sustainable options for traditional plastics, e.g., the application of products derived from waste and wastewater, will arise in the coming years as part of the Circular Economy Action Plan (European Commission 2020).

\section{Extracellular Polymeric Substances}

Extracellular polymeric substances (EPS) are believed to play an important role in the WWTP processes in the formation and stability of both sludge flocs and biofilms, as this self-produced hydrated matrix of large polymeric molecules envelopes bacterial cells [135]. Furthermore, EPS are currently considered as potential resources and thus are key players in the paradigm shift from WWTPs to WRRFs [136]. The EPS are located at the outside of the bacterial cells surface, and their production and composition are thought to be controlled by different processes, such as active secretion, the shedding of cell surface material, cell lysis, and adsorption from the environment [137]. The presence of EPS in sludge contributes to the aggregation of bacterial cells in flocs and biofilms (e.g., granular sludge), bacteria protection acting as barrier against harmful substances, the water-binding capacity, and the enzymatic action such as the digestion of complex macromolecules for nutrient acquisition [138]. In the past, biofilm research often assumed that polysaccharides were the predominant components of EPS [139]. However, proteins, humic acids, fulvic acids, and nucleic acids are also abundant in EPS from several sources [140-142].

The first studies on the recovery of EPS conducted on activated sludge biomass from full-scale WWTPs demonstrated some interesting properties of these biopolymers, such as their bioflocculation [143] and metal biosorption capacities [144-146]. More recently, these interesting properties have also been found in EPS extracted from granular biomasses such as aerobic granular sludge (AGS) and anammox granules.

Although conventionally activated sludge systems are still the most common technology used in WWTPs, systems based on granular sludge have been increasingly adopted worldwide, which is in part due to their high performance and lower footprint [147]. Past studies have revealed that a particular fraction of EPS, named structural EPS (sEPS), has characteristics similar to alginate polymers and, can be extracted from AGS with an yield in the range $20-30 \%$ wt as volatile solids (VS) $[148,149]$. A first comparison between the activated sludge or AGS recovered EPS can be drawn in terms of extraction yield, which is much lower in the case of activated sludge-based EPS (3.5-7.2\% wt as VS) [150]. However, it should be noted that extraction of granular sludge-based sEPS requires more intensive and expensive extraction methods than that of flocs. Nevertheless, in both cases, sEPS extraction reduces the sludge volumes to be disposed (i.e., operational expenditure cost reduction), and the residual sludge could have higher digestibility [151]. The first large-scale 
EPS production unit is already in operation in Zutphen (The Netherlands), and a second production unit in Epe is projected [152]. The EPS, marketed as Kaumera Nereda ${ }^{\circledR}$ Gum, is extracted from granular sludge originating from the Nereda ${ }^{\circledR}$ wastewater treatment process. This process will ensure that 20-35\% less sludge will need to be processed, thus reducing energy consumption and $\mathrm{CO}_{2}$ emissions. Based on the experimental value of $21.9 \% \mathrm{wt}$ as VS of sEPS recovered from a pilot-scale AGS process treating municipal wastewater [153], it is expected that about $22.5 \%$ wt as VS of sEPS can be recovered from waste AGS [154]. More recently, the feasibility of recovering EPS from surplus AGS biomass was assessed in full-scale operational settings [155]. Although variations in the EPS concentration and composition were observed over time overall, it was estimated that the surplus biomass produced at that WWTP would allow for the recovery of 4-5 ton of EPS per day or 0.6-1 ton of purer EPS per day, depending on the composition variability that was aimed for.

Regarding the EPS extracted from anammox granular sludge, the extensive classification of glycoproteins originating from it allowed for the better understanding of their structure [156]. The protein and polysaccharide analyses from the extracted EPS revealed $599 \mathrm{mg} / \mathrm{g} \mathrm{VS}$ EPS and $49 \mathrm{mg} / \mathrm{g}$ VS EPS, respectively [138,157].

Bearing in mind the above, it should be stressed that EPS composition largely depends on various factors such as sampling, the type of wastewater sludge, the operating conditions, and the extraction methods, as shown in Table 11. More exactly, given the high diversity of the granular sludge-based EPS and the applied extraction and recovery methods (i.e., heating-alkaline conditions, acidic conditions, etc.), differences in terms of the yields, components, and functional groups of the EPS are observed [88,102,111]. However, the existing extraction and recovery methods have never been considered in terms of the recoverable material characteristics for specific practical applications and have only been aimed at maximizing the extraction yield. Hence, designing the proper extraction method looking at specific applications is an aspect that requires consideration when it comes to reusing the recovered EPS-based materials in specific industrial sectors.

Some recent studies have estimated that the full-scale recovered AGS-based EPS could reach 85 kton in the Netherlands in the coming decade [154,158]. Likewise, the anammox granular sludge-based EPS could reach $185 \mathrm{~kg}$-EPS/d from full-scale partial nitritation/anammox processes [159].

Table 11. EPS recovery from granular sludge collected at pilot- and full-scale reactors.

\begin{tabular}{|c|c|c|c|c|c|c|}
\hline $\begin{array}{l}\text { Technology and } \\
\text { Waste Stream }\end{array}$ & Scale & Operational Conditions & Extraction Method & $\begin{array}{c}\text { Characteristics of } \\
\text { Polymers }\end{array}$ & Yield & Reference \\
\hline $\begin{array}{l}\text { AGS_industrial } \\
\text { diary wastewater }\end{array}$ & Full-scale SBR & Nereda ${ }^{\circledR}$ process; n.r. & $\begin{array}{c}\text { Heating method } \\
\left(\mathrm{Na}_{2} \mathrm{CO}_{3}, \mathrm{~T}=80^{\circ} \mathrm{C}\right)\end{array}$ & Kaumera ${ }^{\circledR}$ gum; n.r. & $225 \underset{\text { VSS }_{\text {AGS }}^{\text {mg VSS }}}{\text { sEPS } / g}$ & [154] \\
\hline $\begin{array}{l}\text { AGS-municipal } \\
\text { wastewater }\end{array}$ & Full-scale SBR & $\begin{array}{c}\text { Nereda }^{\circledR} \text { process; COD } \\
\text { tot,in = 585 mg/L; } \\
\text { TSS,in = } 195 \mathrm{mg} / \mathrm{L} ; \\
\text { NH4-N,in = 55 mg/L; } \\
\mathrm{PO}_{4}-\mathrm{P}, \text { in }=6.3 \mathrm{mg} / \mathrm{L} ; \\
\text { TSS,react = } 8-10 \mathrm{~g} / \mathrm{L} .\end{array}$ & $\begin{array}{c}\text { Heating method } \\
\left(\mathrm{Na}_{2} \mathrm{CO}_{3}, \mathrm{~T}=80^{\circ} \mathrm{C}\right)\end{array}$ & $\begin{array}{c}69 \pm 9 \% \text { PolyGG blocks; } \\
2 \pm 1 \% \text { PolyMM blocks; } \\
15 \pm 2 \% \text { PolyMG blocks. } \\
\text { Sodium alginate } \\
\text { equivalent: } 486 \pm 22 \mathrm{mg} \\
\text { Alginate } / \mathrm{g} \text { VSS } \mathrm{sEPS} ; \\
\text { Protein: }<100 \mathrm{mg} \text { BSA } / \mathrm{g} \\
\text { VSS } \\
\text { sEPS. }\end{array}$ & $\begin{array}{l}160 \pm 4 \mathrm{mg} \text { VSS } \\
\mathrm{sEPS} / \mathrm{g} \text { VSS } \mathrm{AGS}\end{array}$ & [160] \\
\hline $\begin{array}{l}\text { AGS-municipal } \\
\text { wastewater }\end{array}$ & Full-scale SBR & Nereda ${ }^{\circledR}$ process; n.r. & $\begin{array}{c}\text { Heating method } \\
\left(\mathrm{Na}_{2} \mathrm{CO}_{3}, \mathrm{~T}=80^{\circ} \mathrm{C}\right)\end{array}$ & $\begin{array}{c}\text { Polysaccharides: } 138 \mathrm{mg} \\
\text { Glucose/g VSS sEPS; } \\
\text { Proteins: } 381 \text { mg BSA/g } \\
\text { VSS sEPS;Uronic acid: } \\
72 \text { mg galact. acid/g } \\
\text { VSS sEPs; } \\
\text { Phenolic compound: } \\
286 \text { mg humic acid/g } \\
\text { VSS } \\
\text { sEPS. }\end{array}$ & 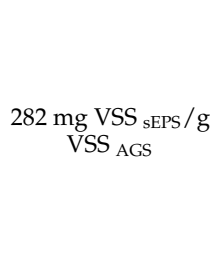 & {$[149,161,162]$} \\
\hline
\end{tabular}


Table 11. Cont.

\begin{tabular}{|c|c|c|c|c|c|c|}
\hline $\begin{array}{l}\text { Technology } \\
\text { and Waste } \\
\text { Stream }\end{array}$ & Scale & Operational Conditions & Extraction Method & $\begin{array}{c}\text { Characteristics of } \\
\text { Polymers }\end{array}$ & Yield & Reference \\
\hline $\begin{array}{l}\text { AGS-mixed } \\
\text { domestic, } \\
\text { pluvial and } \\
\text { industrial } \\
\text { wastewater }\end{array}$ & Full-scale SBR & Nereda ${ }^{\circledR}$ process; n.r. & $\begin{array}{c}\text { Heating method } \\
\left(\mathrm{Na}_{2} \mathrm{CO}_{3}, \mathrm{~T}=80^{\circ} \mathrm{C}\right)\end{array}$ & $\begin{array}{c}\text { Polysaccharides: } \approx \\
10-15 \text { mg Glucose /g } \\
\text { VSS } \\
\text { sEPS; } \\
\text { Proteins: } \approx 60-80 \mathrm{mg} \\
\text { BSA/g VSS } \text { sEPs; } \\
\text { Humic substances: } \\
317 \text { mg humic acid/g } \\
\text { VSS } \\
\text { sEPS. }\end{array}$ & $\begin{array}{l}\text { 122-149 mg VSS } \\
\text { sEPS/g VSS AGS }\end{array}$ & [155] \\
\hline $\begin{array}{l}\text { AGS- } \\
\text { municipal } \\
\text { wastewater }\end{array}$ & $\begin{array}{l}\text { Pilot-scale } \\
\text { SBR }\end{array}$ & $\begin{array}{c}\text { COD tot,in = } 461 \mathrm{mg} / \mathrm{L} ; \\
\text { BOD5,in = } 148 \mathrm{mg} / \mathrm{L} ; \\
\text { TN,in = } 43 \mathrm{mg} / \mathrm{L} ; \\
\text { TP,in }=5 \mathrm{mg} / \mathrm{L} \\
\text { VER }=60 \% ; \\
\text { SRT }=12-15 \text { days. }\end{array}$ & $\begin{array}{c}\text { Heating method } \\
\left(\mathrm{Na}_{2} \mathrm{CO}_{3}, \mathrm{~T}=80^{\circ} \mathrm{C}\right)\end{array}$ & $\begin{array}{c}\text { Polysaccharides: } 136 \text { mg } \\
\text { Glucose/g VSS; } \\
\text { Proteins: } 514 \text { mg } \\
\text { BSA/g VSS. }\end{array}$ & 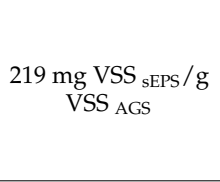 & [153] \\
\hline $\begin{array}{c}\text { AGS- } \\
\text { wastewater } \\
\text { from university } \\
\text { campus }\end{array}$ & $\begin{array}{l}\text { Pilot-scale } \\
\text { SBR }\end{array}$ & $\begin{array}{c}\text { VER }=60 \% \text {; SRT }=10 \mathrm{~d} ; \\
\text { COD tot,in = } 1200 \mathrm{mg} / \mathrm{L} ; \\
\text { TN,in = } 52 \mathrm{mg} / \mathrm{L} ; \\
\text { TP,in }=12 \mathrm{mg} / \mathrm{L} .\end{array}$ & $\begin{array}{l}\text { Cation Exchange } \\
\text { Resin (CER). }\end{array}$ & $\begin{array}{l}\text { Polysaccharides: } \\
\text { 224-252 mg } \\
\text { Glucose/g VSS; } \\
\text { Proteins: } \approx 11 \mathrm{mg} \\
\text { BSA/g VSS. }\end{array}$ & n.r. & [163] \\
\hline $\begin{array}{c}\text { AGS- } \\
\text { synthetic } \\
\text { wastewater }\end{array}$ & $\begin{array}{l}\text { Pilot-scale } \\
\text { SBR }\end{array}$ & $\begin{array}{c}\text { VER }=60 \% \\
\text { COD tot,in = } 8 \mathrm{~g} / \mathrm{L} ; \\
\text { TN,in }=450 \mathrm{mg} / \mathrm{L} \\
\text { TP,in }=90 \mathrm{mg} / \mathrm{L} .\end{array}$ & $\begin{array}{l}\text { Thermal extraction } \\
\qquad\left(\mathrm{T}=80^{\circ} \mathrm{C}\right)\end{array}$ & $\begin{array}{c}\text { Polysaccharides: } 92 \mathrm{mg} \\
\text { Glucose/g VSS; } \\
\text { Proteins: 144 mg } \\
\text { BSA/g VSS. }\end{array}$ & n.r. & [164] \\
\hline Anammox & Full-scale & $\begin{array}{c}\text { Two stage partial } \\
\text { nitritation-anammox. }\end{array}$ & $\begin{array}{l}\text { Alkaline extraction } \\
(\mathrm{NaOH})\end{array}$ & $\begin{array}{c}\text { Polysaccharides: } \\
\text { 4-287 mg } \\
\text { Glucose/g VSS; } \\
\text { Proteins: 17-307 mg } \\
\text { BSA/g VSS. }\end{array}$ & $\begin{array}{l}\text { up to } 380 \mathrm{mg} \text { VSS } \\
\text { sEPS } / \mathrm{g} \text { VSS } \mathrm{AMX}\end{array}$ & {$[136,138,156,165]$} \\
\hline
\end{tabular}

n.r.—not reported; SBR—sequencing batch reactor; VER—volumetric exchange ratio; SRT—sludge retention time; GG—guluronic blocks; $\mathrm{MM}$-mannuronic blocks; MG-heteropolymeric blocks.

EPS recovery will lead to a reduction in the amount of waste sludge to be disposed, thus promoting a paradigm-shift from WWTPs to WRRFs. Furthermore, the peculiar characteristics of the recovered EPS make them a resource that should be used as much as possible. Currently, there are numerous applications for the EPS recovered from waste biomass (Table 12). EPS could potentially be used in the chemical, agriculture, or building sectors, among others.

The EPS recovered from granular sludge were found to be able to form hydrogels with peculiar rheological properties $[136,166]$. The hydrogel-forming capacity of sEPS allows for their potential application as an industrial paper coating to increase the waterproof properties $[167,168]$. The hydrophilic and hydrophobic functional groups present in EPS provide abundant binding sites, which are closely related to the hydrogel enhanced features.

As AGS-based sEPS have hydrophilic characteristics, they can be commercially applied to improve the curing of cement [166]. The mechanism is related to reducing moisture loss from the surface of cement-based materials, which is fundamental in construction engineering [169]. The retention of cement surface humidity is very important to avoid structural cracking due to drying shrinkage.

Additionally, granular sludge-based EPS have been proven to be a cost-effective biosorbent material for several water treatments, as they are able to bind metal ions $\left(\mathrm{Ni}^{2+}\right.$, $\left.\mathrm{Pb}^{2+}, \mathrm{Cd}^{2+}\right)[170,171]$ or organic compounds [172]. Nevertheless, it should be stressed that the biosorption effectiveness of granular sludge-based EPS strictly depends on $\mathrm{pH}$, temperature, conductivity, efficient contact area/time between EPS and pollutants, and pollutant structure and concentration [170].

Another property of AGS-based sEPS is regarding their possibility to be used as extinguished bio-based flame retardant materials for flax fabrics due to their effective char formation [173]. EPS have self-extinguishing properties, indicating their feasible application as coating materials [173]. To date, the market for flame retardants comprises almost $31 \%$ halogenated materials even though they have hazardous influences on humans 
and on the environment. In this context, the EPS extracted from granular sludge could be a "green" bio-based alternative, reducing the consumption of halogenated materials.

Table 12. Applications of the recovered EPS in the different industrial sectors.

\begin{tabular}{|c|c|c|}
\hline Application of EPS & Features & Reference \\
\hline Coating material & $\begin{array}{l}\text { The functional groups present in EPS } \\
\text { provide abundant binding sites, both } \\
\text { hydrophilic and hydrophobic } \\
\text { functional groups, conferring improved } \\
\text { waterproof capacity to surfaces. }\end{array}$ & {$[167,168]$} \\
\hline Curing of cement & $\begin{array}{l}\text { The hydrophilic properties of the EPS } \\
\text { improve the curing of cement, reducing } \\
\text { moisture loss from the surface of } \\
\text { cement-based materials }\end{array}$ & [166] \\
\hline Bioadsorbent & $\begin{array}{l}\text { The physicochemical interactions } \\
\text { between the adsorbates and functional } \\
\text { groups of EPS, promote the adsorption } \\
\text { of metals or other compounds }\end{array}$ & {$[170,171]$} \\
\hline Flame retardant & $\begin{array}{l}\text { sEPS can be extinguished bio-based } \\
\text { flame retardant materials for flax } \\
\text { fabrics due to effective char formation. }\end{array}$ & [173] \\
\hline Bioflocculation & $\begin{array}{l}\text { Some functional groups present on the } \\
\text { EPS contribute to the flocculation } \\
\text { abilities of these biopolymers }\end{array}$ & [174] \\
\hline Soil conditioning & $\begin{array}{l}\text { The water-binding capacity makes EPS } \\
\text { applicable in the agronomic sector, as } \\
\text { these biopolymers are able to retain } \\
\text { water in soil and to reduce the leaching } \\
\text { of fertilizers. }\end{array}$ & [175] \\
\hline
\end{tabular}

Recently, the potential application of EPS as bio-flocculants in place of synthetic polyelectrolytes was reported [174]. The EPS functional composition in this case plays an important role in the flocculation ability as the presence of some functional groups improve the agglomeration of particulate matter and floc formation.

A recent application of sEPS lies in the agronomic sector as a soil conditioner [175]. They can be applied as a bio-stimulant and as a slow-release fertilizer. sEPS can retain water (water-binding capacity) [138] and thus improve plant growth.

\section{Conclusions}

To meet the global challenges, e.g., increasing water demand, water shortage, and decreasing availability of non-renewable resources, the adoption of the so-called WRRF concept is crucial. Nowadays, sewage is no longer regarded as a waste but rather as a source of valuable resources, resulting in environmental and social-economic benefits. To date, the resource recovery concept has been successfully applied in pilot- and fullscale facilities. Wastewater treatment for reuse is indeed a plausible solution to combat the world's water scarcity problem. The available technologies allow wastewater to be properly treated, producing effluents with quality that satisfies the demand from different sectors, including industry and agriculture. However, scientific advances have shown that wastewater valorization is not limited to water reuse, recognizing that wastewater contains several valuable resources that can be recovered. Concerning the excess of sludge produced during wastewater treatment, several strategies can be applied to valorize this waste sludge. Sludge composting and anaerobic sludge digestion are already widely applied at full-scale processes, but more options for sludge valorization are feasible and effective. Nevertheless, the integration of the water sector in the circular economy concept can only be performed if 
a close cooperation between governments, science, and commercial companies is targeted. More in-depth studies on cost analysis and safety could help increase the use of the proposed technologies as viable alternatives. Moreover, even though the market value of the recovered materials may not be high enough to justify its application, valorization strategies are more promising than traditional disposal methods, as they create value and reduce pollution.

Author Contributions: Conceptualization, A.F.D., R.C., A.V.d.R, and C.L.A.; writing-original draft preparation A.F.D. and C.L.A.; writing-review and editing, A.F.D., R.C., A.V.d.R. and C.L.A. All authors have read and agreed to the published version of the manuscript.

Funding: This work was financed by national funds from the FCT-Fundação para a Ciência e a Tecnologia, I.P. through the projects Beer2BioPol-PTDC/BTA-BTA/31746/2017 and GReATPTDC/BTA-BTA/29970/2017 (POCI-01-0145-FEDER-029970). The authors would also like to thank the FCT under the scope of the project UIDP/04378/2020 and UIDB/04378/2020 of the Research Unit on Applied Molecular Biosciences-UCIBIO, project LA/P/0140/2020 of the Associate Laboratory Institute for Health and Bioeconomy-i4HB, and the project UIDB/50016/2020 of the CBQF.

Conflicts of Interest: The authors declare no conflict of interest.

\section{References}

1. OECD (Ed.) OECD Environmental Outlook to 2050; OECD Environmental Outlook; OECD: Paris, France, $2012 ;$ ISBN 9789264122161.

2. Kehrein, P.; Van Loosdrecht, M.; Osseweijer, P.; Garfí, M.; Dewulf, J.; Posada, J. A critical review of resource recovery from municipal wastewater treatment plants-market supply potentials, technologies and bottlenecks. Environ. Sci. Water Res. Technol. 2020, 6, 877-910. [CrossRef]

3. UN General Assembly. Transforming Our World: The 2030 Agenda for Sustainable Development; United Nations: New York, NY, USA, 2015.

4. Gude, V.G. Energy and water autarky of wastewater treatment and power generation systems. Renew. Sustain. Energy Rev. 2015, 45, 52-68. [CrossRef]

5. Rodriguez, D.J.; Serrano, H.A.; Delgado, A.; Nolasco, D.; Saltiel, G. From Waste to Resource-Shifting Paradigms for Smarter Wastewater Interventions in Latin America and the Caribbean; World Bank: Washington, DC, USA, 2020.

6. Smith, K.M.; Fowler, G.D.; Pullket, S.; Graham, N.J.D. Sewage sludge-based adsorbents: A review of their production, properties and use in water treatment applications. Water Res. 2009, 43, 2569-2594. [CrossRef] [PubMed]

7. Palmieri, S.; Cipolletta, G.; Pastore, C.; Giosuè, C.; Akyol, Ç.; Eusebi, A.L.; Frison, N.; Tittarelli, F.; Fatone, F. Pilot scale cellulose recovery from sewage sludge and reuse in building and construction material. Waste Manag. 2019, 100, 208-218. [CrossRef]

8. Liu, Z.; Smith, S.R. Enzyme Recovery from Biological Wastewater Treatment. Waste Biomass Valorization 2021, $12,4185-4211$. [CrossRef]

9. Golnaraghi Ghomi, A.; Asasian-Kolur, N.; Sharifian, S.; Golnaraghi, A. Biosorpion for sustainable recovery of precious metals from wastewater. J. Environ. Chem. Eng. 2020, 8, 103996. [CrossRef]

10. Food and Agriculture Organization of the United Nations. The State of the World's Land and Water Resources for Food and Agriculture (SOLAW)_Managing Systems at Risk; The Food and Agriculture Organization of the United Nations and Earthscan: Rome, Italy; London, UK, 2011; ISBN 9781849713269.

11. Ofori, S.; Puškáčová, A.; Růžičková, I.; Wanner, J. Treated wastewater reuse for irrigation: Pros and cons. Sci. Total Environ. 2021, 760, 144026. [CrossRef]

12. European Commission. Study to support the Commission's Impact Assessment of an EU level instrument on water reuse-Final report EU-level instruments on water reuse. In Final Report to Support the Commission's Impact Assessment; Publication Office of the European Union: Luxembourg, 2016. [CrossRef]

13. Lafforgue, M. Supplying water to a water-stressed city: Lessons from Windhoek. La Houille Blanche 2016, 102, 40-47. [CrossRef]

14. Fluence-News-Team Israel Leads World in Water Recycling. Available online: https://www.fluencecorp.com/israel-leads-worldin-water-recycling (accessed on 13 August 2021).

15. Messing, A.; Sela, Y. SHAFDAN (Greater Tel Aviv Wastewater Treatment Plant): Recent upgrade and expansion. Water Pract. Technol. 2016, 11, 288-297. [CrossRef]

16. Holmgren, K.E.; Li, H.; Verstraete, W.; Cornel, P. State of the Art Compendium Report on Resource Recovery from Water; IWA: London, UK, 2016.

17. Dutta, D.; Arya, S.; Kumar, S. Industrial wastewater treatment: Current trends, bottlenecks, and best practices. Chemosphere 2021, 285, 131245. [CrossRef]

18. SSWM Wastewater Reuse in Industry. Available online: https://sswm.info/water-nutrient-cycle/water-use/hardwares/ optimisation-water-use-industries/wastewater-reuse-in-industry (accessed on 13 August 2021). 
19. Aich, N.; Nama, S.; Biswal, A.; Paul, T. A review on recirculating aquaculture systems: Challenges and opportunities for sustainable aquaculture. Inno. Farm. 2020, 5, 17-24.

20. Verhuelsdonk, M.; Glas, K.; Parlar, H. Economic evaluation of the reuse of brewery wastewater. J. Environ. Manag. 2021, 281, 111804. [CrossRef]

21. Vergine, P.; Salerno, C.; Libutti, A.; Beneduce, L.; Gatta, G.; Berardi, G.; Pollice, A. Closing the water cycle in the agro-industrial sector by reusing treated wastewater for irrigation. J. Clean. Prod. 2017, 164, 587-596. [CrossRef]

22. Fraga, F.A.; García, H.A.; Hooijmans, C.M.; Míguez, D.; Brdjanovic, D. Evaluation of a membrane bioreactor on dairy wastewater treatment and reuse in Uruguay. Int. Biodeterior. Biodegrad. 2017, 119, 552-564. [CrossRef]

23. Murray, F.; Bostock, J.; Fletcher, D. Review of Recirculation Aquaculture System Technologies and Their Commercial Application. Final Report March 2014; Highlands and Islands Enterprise: Inverness, UK, 2014.

24. Ahmed, N.; Turchini, G.M. Recirculating aquaculture systems (RAS): Environmental solution and climate change adaptation. J. Clean. Prod. 2021, 297, 126604. [CrossRef]

25. Bauer, S.; Linke, H.J.; Wagner, M. Combining industrial and urban water-reuse concepts for increasing the water resources in water-scarce regions. Water Environ. Res. 2020, 92, 1027-1041. [CrossRef]

26. European Commission. EU-Level Instruments on Water Reuse-Final Report to Support the Commission's Impact Assessment; European Commission: Brussels, Belgium, 2016.

27. Water Reuse Europe Water Reuse Europe-Policy and Regulations. Available online: https://ec.europa.eu/environment/water/ blueprint/pdf/EU_level_instruments_on_water-2nd-IA_support-study_AMEC.pdf (accessed on 13 August 2021).

28. Dingemans, M.M.L.; Smeets, P.W.M.H.; Medema, G.; Frijns, J.; Raat, K.J.; van Wezel, A.P.; Bartholomeus, R.P. Responsible water reuse needs an interdisciplinary approach to balance risks and benefits. Water 2020, 12, 1264. [CrossRef]

29. EPA. Safe. Drinking Water ACT-(Title XIV of Public Health Service ACT); EPA: Washington, DC, USA, 1944.

30. EPA. Clean Water Laws, Regulations, and Executive Orders related to Section 404; EPA: Washington, DC, USA, 1972.

31. EPA. Guidelines for Water Reuse. EPA/600/R-12/618; EPA: Washington, DC, USA, 2012.

32. EPA. Water Reuse Action Plan. Available online: https://www.epa.gov/waterreuse/water-reuse-action-plan (accessed on 13 August 2021).

33. EPA. National Water Reuse Action Plan; EPA: Washington, DC, USA, 2020.

34. Christian-Smith, J.; Gleick, P.H.; Ross, N.; Allen, L.; Cohen, M.J.; Schulte, P.; Smith, C. California Farm Water Success Stories; Pacific Institute: Oakland, CA, USA, 2010.

35. Kirhensteine, I.; Cherrier, V.; Jarritt, N.; Farmer, A.; de Paoli, G.; Delacamara, G.; Psomas, A. EU-Level Instruments on Water Reuse; European Union: Luxembourg, 2016; ISBN 9789279626166.

36. Radcliffe, J.C.; Page, D. Water reuse and recycling in Australia-History, current situation and future perspectives. Water Cycle 2020, 1, 19-40. [CrossRef]

37. Kacprzak, M.; Neczaj, E.; Fijałkowski, K.; Grobelak, A.; Grosser, A.; Worwag, M.; Rorat, A.; Brattebo, H.; Almås, Å.; Singh, B.R. Sewage sludge disposal strategies for sustainable development. Environ. Res. 2017, 156, 39-46. [CrossRef]

38. European Union. Directive 2008/98/EC of the European Parliament and of the Council of 19 November 2008 on Waste and Repealing Certain Directives (Text with EEA Relevance); European Union: Luxembourg, 2008.

39. Hussain, F.; Shah, S.Z.; Ahmad, H.; Abubshait, S.A.; Abubshait, H.A.; Laref, A.; Manikandan, A.; Kusuma, H.S.; Iqbal, M. Microalgae an ecofriendly and sustainable wastewater treatment option: Biomass application in biofuel and bio-fertilizer production. A review. Renew. Sustain. Energy Rev. 2021, 137, 110603. [CrossRef]

40. Renuka, N.; Sood, A.; Prasanna, R.; Ahluwalia, A.S. Phycoremediation of wastewaters: A synergistic approach using microalgae for bioremediation and biomass generation. Int. J. Environ. Sci. Technol. 2015, 12, 1443-1460. [CrossRef]

41. Mu, R.; Jia, Y.; Ma, G.; Liu, L.; Hao, K.; Qi, F.; Shao, Y. Advances in the use of microalgal-bacterial consortia for wastewater treatment: Community structures, interactions, economic resource reclamation, and study techniques. Water Environ. Res. 2020, 93, 1217-1230. [CrossRef]

42. Mantovani, M.; Marazzi, F.; Fornaroli, R.; Bellucci, M.; Ficara, E.; Mezzanotte, V. Outdoor pilot-scale raceway as a microalgaebacteria sidestream treatment in a WWTP. Sci. Total Environ. 2020, 710, 135583. [CrossRef]

43. Pizzera, A.; Scaglione, D.; Bellucci, M.; Marazzi, F.; Mezzanotte, V.; Parati, K.; Ficara, E. Digestate treatment with algae-bacteria consortia: A field pilot-scale experimentation in a sub-optimal climate area. Bioresour. Technol. 2019, 274, 232-243. [CrossRef]

44. Marazzi, F.; Ficara, E.; Fornaroli, R.; Mezzanotte, V. Factors Affecting the Growth of Microalgae on Blackwater from Biosolid Dewatering. Water Air Soil Pollut. 2017, 228, 68. [CrossRef]

45. Marazzi, F.; Bellucci, M.; Rossi, S.; Fornaroli, R.; Ficara, E.; Mezzanotte, V. Outdoor pilot trial integrating a sidestream microalgae process for the treatment of centrate under non optimal climate conditions. Algal Res. 2019, 39, 101430. [CrossRef]

46. Villegas, G.I.R.; Fiamengo, M.; Fernández, F.G.A.; Grima, E.M. Outdoor production of microalgae biomass at pilot-scale in seawater using centrate as the nutrient source. Algal Res. 2017, 25, 538-548. [CrossRef]

47. Ren, H.; Tuo, J.; Addy, M.M.; Zhang, R.; Lu, Q.; Anderson, E.; Chen, P.; Ruan, R. Cultivation of Chlorella vulgaris in a pilot-scale photobioreactor using real centrate wastewater with waste glycerol for improving microalgae biomass production and wastewater nutrients removal. Bioresour. Technol. 2017, 245, 1130-1138. [CrossRef]

48. Tan, X.; Chu, H.; Zhang, Y.; Yang, L.; Zhao, F.; Zhou, X. Chlorella pyrenoidosa cultivation using anaerobic digested starch processing wastewater in an airlift circulation photobioreactor. Bioresour. Technol. 2014, 170, 538-548. [CrossRef] 
49. Lu, W.; Wang, Z.; Wang, X.; Yuan, Z. Cultivation of Chlorella sp. using raw dairy wastewater for nutrient removal and biodiesel production: Characteristics comparison of indoor bench-scale and outdoor pilot-scale cultures. Bioresour. Technol. 2015, 192, 382-388. [CrossRef]

50. Kumar, A.K.; Sharma, S.; Dixit, G.; Shah, E.; Patel, A. Techno-economic analysis of microalgae production with simultaneous dairy effluent treatment using a pilot-scale High Volume V-shape pond system. Renew. Energy 2020, 145, 1620-1632. [CrossRef]

51. Hena, S.; Znad, H.; Heong, K.T.; Judd, S. Dairy farm wastewater treatment and lipid accumulation by Arthrospira platensis. Water Res. 2018, 128, 267-277. [CrossRef]

52. Silveira, C.F.; de Assis, L.R.; Paulo, A.; Oliveira, D.S.; Calijuri, M.L. Valorization of swine wastewater in a circular economy approach: Effects of hydraulic retention time on microalgae cultivation. Sci. Total Environ. 2021, 789, 147861. [CrossRef] [PubMed]

53. de Godos, I.; Blanco, S.; García-Encina, P.A.; Becares, E.; Muñoz, R. Long-term operation of high rate algal ponds for the bioremediation of piggery wastewaters at high loading rates. Bioresour. Technol. 2009, 100, 4332-4339. [CrossRef] [PubMed]

54. Chen, Y.; Jiang, S.; Yuan, H.; Zhou, Q.; Gu, G. Hydrolysis and acidification of waste activated sludge at different pHs. Water Res. 2007, 41, 683-689. [CrossRef] [PubMed]

55. Hülsen, T.; Carvalho, G.; Egger, F.; Cruz, H.; Vertstraete, W.; Batstone, D.J.; Pikaar, I. Production of single-cell proteins from organic matter and residual nitrogen. In Wastewater Treatment Residues as Resources for Biorefinery Products and Biofuels; Elsevier: Amsterdam, The Netherlands, 2020; pp. 355-389. [CrossRef]

56. Lee, J.Z.; Logan, A.; Terry, S.; Spear, J.R. Microbial response to single-cell protein production and brewery wastewater treatment. Microb. Biotechnol. 2015, 8, 65-76. [CrossRef]

57. Oesterholt, F.I.H.M.; Palmen, L.; Verstraete, W.; Boere, J. Power-to-Protein: Next step towards consumable single cell proteins from waste water and renewable hydrogen. In Proceedings of the 3rd IWA Resource Recovery Conference, Venice, Italy, 8-12 September 2019.

58. Villamil, J.A.; Chacon, S.; Moreno, E.; Molina, R.; Martinez, F.; Melero, J.A.; Puyol, D. Quick start-up of a novel purple photosyntehtic bacteria-based anaerobic raceway at pilot scale for resource recovery from mixed urban biowaste sources. In Proceedings of the 5th International Conference on Ecotechnologies for Wastewater Treatment, Milan, Italy, 21-25 June 2021.

59. Santos, A.F.; Almeida, P.V.; Alvarenga, P.; Gando-Ferreira, L.M.; Quina, M.J. From wastewater to fertilizer products: Alternative paths to mitigate phosphorus demand in European countries. Chemosphere 2021, 284, 131258. [CrossRef]

60. Hülsen, T.; Hsieh, K.; Lu, Y.; Tait, S.; Batstone, D.J. Simultaneous treatment and single cell protein production from agri-industrial wastewaters using purple phototrophic bacteria or microalgae-A comparison. Bioresour. Technol. 2018, 254, 214-223. [CrossRef]

61. Capson-Tojo, G.; Batstone, D.J.; Grassino, M.; Vlaeminck, S.E.; Puyol, D.; Verstraete, W.; Kleerebezem, R.; Oehmen, A.; Ghimire, A.; Pikaar, I.; et al. Purple phototrophic bacteria for resource recovery: Challenges and opportunities. Biotechnol. Adv. 2020, 43, 107567. [CrossRef]

62. Kleemann, R.; Chenoweth, J.; Clift, R.; Morse, S.; Pearce, P.; Saroj, D. Evaluation of local and national effects of recovering phosphorus at wastewater treatment plants: Lessons learned from the UK. Resour. Conserv. Recycl. 2015, 105, 347-359. [CrossRef]

63. Zhou, K.; Barjenbruch, M.; Kabbe, C.; Inial, G.; Remy, C. Phosphorus recovery from municipal and fertilizer wastewater: China's potential and perspective. J. Environ. Sci. 2017, 52, 151-159. [CrossRef]

64. Saliu, T.D.; Oladoja, N.A. Nutrient recovery from wastewater and reuse in agriculture: A review. Environ. Chem. Lett. 2021, 19, 2299-2316. [CrossRef]

65. Crutchik, D.; Morales, N.; Vázquez-Padín, J.R.; Garrido, J.M. Enhancement of struvite pellets crystallization in a full-scale plant using an industrial grade magnesium product. Water Sci. Technol. 2017, 75, 609-618. [CrossRef]

66. Brienza, C.; Sigurnjak, I.; Meier, T.; Michels, E.; Adani, F.; Schoumans, O.; Vaneeckhaute, C.; Meers, E. Techno-economic assessment at full scale of a biogas refinery plant receiving nitrogen rich feedstock and producing renewable energy and biobased fertilisers. J. Clean. Prod. 2021, 308, 127408. [CrossRef]

67. Richter, L.; Wichern, M.; Grömping, M.; Robecke, U.; Haberkamp, J. Ammonium recovery from process water of digested sludge dewatering by membrane contactors. Water Pract. Technol. 2020, 15, 84-91. [CrossRef]

68. Ye, Y.; Ngo, H.H.; Guo, W.; Liu, Y.; Chang, S.W.; Nguyen, D.D.; Liang, H.; Wang, J. A critical review on ammonium recovery from wastewater for sustainable wastewater management. Bioresour. Technol. 2018, 268, 749-758. [CrossRef]

69. Gherghel, A.; Teodosiu, C.; De Gisi, S. A review on wastewater sludge valorisation and its challenges in the context of circular economy. J. Clean. Prod. 2019, 228, 244-263. [CrossRef]

70. Egle, L.; Rechberger, H.; Krampe, J.; Zessner, M. Phosphorus recovery from municipal wastewater: An integrated comparative technological, environmental and economic assessment of P recovery technologies. Sci. Total Environ. 2016, 571, 522-542. [CrossRef]

71. USGOV. Standards for the Use or Disposal of Sewage Sludge; USGOV: Washington, DC, USA, 2018.

72. Cecconet, D.; Raček, J.; Callegari, A.; Hlavínek, P. Energy recovery from wastewater: A study on heating and cooling of a multipurpose building with sewage-reclaimed heat energy. Sustainabillity 2020, 12, 116. [CrossRef]

73. Meegoda, J.N.; Li, B.; Patel, K.; Wang, L.B. A Review of the Processes, Parameters, and Optimization of Anaerobic Digestion. Int. J. Environ. Res. Public Health 2018, 15, 2224. [CrossRef]

74. Hanum, F.; Yuan, L.C.; Kamahara, H.; Aziz, H.A. Treatment of Sewage Sludge Using Anaerobic Digestion in Malaysia: Current State and Challenges. Front. Energy Res. 2019, 7, 19. [CrossRef] 
75. Ince, O.; Gurol, Z.C.; Ozbayram, E.G.; Iglesias, M.M.; Ince, B.; Massalha, N.; Robles, Á.; Sabbah, I.; Seco, A. Anaerobic treatment of municipal wastewater. In Innovative Wastewater Treatment E Resource Recovery Technologies: Impacts on Energy, Economy and Environment; Lema, J.M., Suarez, S., Eds.; IWA Publishing: London, UK, 2017; ISBN 9781780407876.

76. Nghiem, L.D.; Koch, K.; Bolzonella, D.; Drewes, J.E. Full scale co-digestion of wastewater sludge and food waste: Bottlenecks and possibilities. Renew. Sustain. Energy Rev. 2017, 72, 354-362. [CrossRef]

77. Serna-García, R.; Ruiz-Barriga, P.; Noriega-Hevia, G.; Serralta, J.; Pach, M. Maximising resource recovery from wastewater grown microalgae and primary sludge in an anaerobic membrane co-digestion pilot plant coupled to a composting process. J. Environ. Manag. 2021, 281, 111890. [CrossRef] [PubMed]

78. Bolzonella, D.; Battistoni, P. Anaerobic codigestion of waste activated sludge and OFMSW: The experiences of Viareggio and Treviso plants (Italy) Anaerobic codigestion of waste activated sludge and OFMSW: The experiences of Viareggio and Treviso plants (Italy). Water Sci. Technol. 2006, 58, 203-211. [CrossRef]

79. Razaviarani, V.; Buchanan, I.D.; Malik, S.; Katalambula, H. Pilot-scale anaerobic co-digestion of municipal wastewater sludge with biodiesel waste glycerin. Bioresour. Technol. 2013, 133, 206-212. [CrossRef]

80. Maragkaki, A.E.; Fountoulakis, M.; Gypakis, A.; Kyriakou, A.; Lasaridi, K.; Manios, T. Pilot-scale anaerobic co-digestion of sewage sludge with agro-industrial by-products for increased biogas production of existing digesters at wastewater treatment plants. Waste Manag. 2017, 59, 362-370. [CrossRef]

81. Le Hyaric, R.; Canler, J.-P.; Barillon, B.; Naquin, P.; Gourdon, R. Pilot-scale anaerobic digestion of screenings from wastewater treatment plants. Bioresour. Technol. 2010, 101, 9006-9011. [CrossRef]

82. Wickham, R.; Xie, S.; Galway, B.; Bustamante, H.; Nghiem, L.D. Pilot-scale operation experience of anaerobic Co-digestion for possible full scale implementation. Int. Biodeterior. Biodegrad. 2019, 142, 137-142. [CrossRef]

83. Li, C.; Wang, X.; Zhang, G.; Li, J.; Li, Z.; Yu, G.; Wang, Y. A process combining hydrothermal pretreatment, anaerobic digestion and pyrolysis for sewage sludge dewatering and co-production of biogas and biochar: Pilot-scale veri fi cation. Bioresour. Technol. 2018, 254, 187-193. [CrossRef]

84. Barroso Soares, R.; Ferreira Martins, M.; Franci Gonçalves, R. Experimental investigation of wastewater microalgae in a pilot-scale downdraft gasifier. Algal Res. 2020, 51, 102049. [CrossRef]

85. Gajda, I.; Greenman, J.; Ieropoulos, I.A. Recent advancements in real-world microbial fuel cell applications. Curr. Opin. Electrochem. 2018, 11, 78-83. [CrossRef]

86. Hiegemann, H.; Herzer, D.; Nettmann, E.; Lübken, M.; Schulte, P.; Schmelz, K.G.; Gredigk-Hoffmann, S.; Wichern, M. An integrated $45 \mathrm{~L}$ pilot microbial fuel cell system at a full-scale wastewater treatment plant. Bioresour. Technol. 2016, 218, 115-122 [CrossRef]

87. Wu, S.; Li, H.; Zhou, X.; Liang, P.; Zhang, X.; Jiang, Y.; Huang, X. A novel pilot-scale stacked microbial fuel cell for efficient electricity generation and wastewater treatment. Water Res. 2016, 98, 396-403. [CrossRef]

88. Tota-Maharaj, K.; Paul, P. Performance of pilot-scale microbial fuel cells treating wastewater with associated bioenergy production in the Caribbean context. Int. J. Energy Environ. Eng. 2015, 6, 213-220. [CrossRef]

89. Dong, Y.; Qu, Y.; He, W.; Du, Y.; Liu, J.; Han, X.; Feng, Y. A 90-liter stackable baffled microbial fuel cell for brewery wastewater treatment based on energy self-sufficient mode. Bioresour. Technol. 2015, 195, 66-72. [CrossRef]

90. Liang, P.; Duan, R.; Jiang, Y.; Zhang, X.; Qiu, Y.; Huang, X. One-year operation of 1000-L modularized microbial fuel cell for municipal wastewater treatment. Water Res. 2018, 141, 1-8. [CrossRef]

91. Wainaina, S.; Lukitawesa; Kumar Awasthi, M.; Taherzadeh, M.J. Bioengineering of anaerobic digestion for volatile fatty acids, hydrogen or methane production: A critical review. Bioengineered 2019, 10, 437-458. [CrossRef]

92. Carvalheira, M.; Duque, A.F. From Food Waste to Volatile Fatty Acids towards a Circular Economy. In Fermentation-Processes, Benefits and Risks; IntechOpen: London, UK, 2021.

93. Eggeman, T.; Verser, D. Recovery of organic acids from fermentation broths. Appl. Biochem. Biotechnol. 2005, 122, 605-618. [CrossRef]

94. Atasoy, M.; Owusu-Agyeman, I.; Plaza, E.; Cetecioglu, Z. Bio-based volatile fatty acid production and recovery from waste streams: Current status and future challenges. Bioresour. Technol. 2018, 268, 773-786. [CrossRef]

95. Lee, W.S.; Chua, A.S.M.; Yeoh, H.K.; Ngoh, G.C. A review of the production and applications of waste-derived volatile fatty acids. Chem. Eng. J. 2014, 235, 83-99. [CrossRef]

96. Garcia-Aguirre, J.; Esteban-Gutiérrez, M.; Irizar, I.; González-Mtnez de Goñi, J.; Aymerich, E. Continuous acidogenic fermentation: Narrowing the gap between laboratory testing and industrial application. Bioresour. Technol. 2019, 282, 407-416. [CrossRef]

97. Reis, M.; Albuquerque, M.; Villano, M.; Majone, M. Mixed culture processes for polyhydroxyalkanoate production from agroindustrial surplus/wastes as feedstocks. In Encyclopaedia Comprehensive Biotechnology; Elsevier: Amsterdam, The Netherlands, 2011; Volume 1, pp. 669-684. ISBN 9780080885049.

98. Chen, J.L.; Ortiz, R.; Steele, T.W.J.J.; Stuckey, D.C. Toxicants inhibiting anaerobic digestion: A review. Biotechnol. Adv. 2014, 32, 1523-1534. [CrossRef]

99. Lin, L.; Li, X. Yan Acidogenic fermentation of iron-enhanced primary sedimentation sludge under different $\mathrm{pH}$ conditions for production of volatile fatty acids. Chemosphere 2018, 194, 692-700. [CrossRef]

100. Veluchamy, C.; Kalamdhad, A.S. Biochemical methane potential test for pulp and paper mill sludge with different food/microorganisms ratios and its kinetics. Int. Biodeterior. Biodegrad. 2017, 117, 197-204. [CrossRef] 
101. Da Ros, C.; Conca, V.; Eusebi, A.L.; Frison, N.; Fatone, F. Sieving of municipal wastewater and recovery of bio-based volatile fatty acids at pilot-scale. Water Res. 2020, 174, 115633. [CrossRef]

102. Longo, S.; Katsou, E.; Malamis, S.; Frison, N.; Renzi, D.; Fatone, F. Recovery of volatile fatty acids from fermentation of sewage sludge in municipal wastewater treatment plants. Bioresour. Technol. 2015, 175, 436-444. [CrossRef]

103. Liu, H.; Han, P.; Liu, H.; Zhou, G.; Fu, B.; Zheng, Z. Full-scale production of VFAs from sewage sludge by anaerobic alkaline fermentation to improve biological nutrients removal in domestic wastewater. Bioresour. Technol. 2018, 260, 105-114. [CrossRef]

104. Balasubramanian, S.; Tyagi, R.D. Value-added bio-products from sewage sludge. In Current Developments in Biotechnology and Bioengineering: Solid Waste Management; Elsevier: Amsterdam, The Netherlands, 2017; ISBN 9780444636751.

105. Albuquerque, M.G.E.; Eiroa, M.; Torres, C.; Nunes, B.R.; Reis, M.A.M. Strategies for the development of a side stream process for polyhydroxyalkanoate (PHA) production from sugar cane molasses. J. Biotechnol. 2007, 130, 411-421. [CrossRef]

106. Możejko-Ciesielska, J.; Kiewisz, R. Bacterial polyhydroxyalkanoates: Still fabulous? Microbiol. Res. 2016, 192, 271-282. [CrossRef]

107. Raza, Z.A.; Abid, S.; Banat, I.M. Polyhydroxyalkanoates: Characteristics, production, recent developments and applications. Int. Biodeterior. Biodegrad. 2018, 126, 45-56. [CrossRef]

108. Cinelli, P.; Mallegni, N.; Gigante, V.; Montanari, A.; Seggiani, M.; Coltelli, M.B.; Bronco, S.; Lazzeri, A. Biocomposites based on polyhydroxyalkanoates and natural fibres from renewable byproducts. Appl. Food Biotechnol. 2019, 6, 35-43. [CrossRef]

109. Tomé, L.C.; Pinto, R.J.B.; Trovatti, E.; Freire, C.S.R.; Silvestre, A.J.D.; Neto, C.P.; Gandini, A. Transparent bionanocomposites with improved properties prepared from acetylated bacterial cellulose and poly(lactic acid) through a simple approach. Green Chem. 2011, 13, 419-427. [CrossRef]

110. Sabapathy, P.C.; Devaraj, S.; Meixner, K.; Anburajan, P.; Kathirvel, P.; Ravikumar, Y.; Zabed, H.M.; Qi, X. Recent developments in Polyhydroxyalkanoates (PHAs) production-A review. Bioresour. Technol. 2020, 306, 123132. [CrossRef] [PubMed]

111. Mannina, G.; Presti, D.; Montiel-Jarillo, G.; Carrera, J.; Suárez-Ojeda, M.E. Recovery of polyhydroxyalkanoates (PHAs) from wastewater: A review. Bioresour. Technol. 2020, 297, 122478. [CrossRef]

112. Duque, A.F.; Oliveira, C.S.S.; Carmo, I.T.D.; Gouveia, A.R.; Pardelha, F.; Ramos, A.M.; Reis, M.A.M. Response of a three-stage process for PHA production by mixed microbial cultures to feedstock shift: Impact on polymer composition. New Biotechnol. 2014, 31, 276-288. [CrossRef]

113. Gouveia, A.R.; Freitas, E.B.; Galinha, C.F.; Carvalho, G.; Duque, A.F.; Reis, M.A.M. Dynamic change of pH in acidogenic fermentation of cheese whey towards polyhydroxyalkanoates production: Impact on performance and microbial population. New Biotechnol. 2017, 37, 108-116. [CrossRef]

114. Ribau Teixeira, M.; Guarda, E.C.; Freitas, E.B.; Galinha, C.F.; Duque, A.F.; Reis, M.A.M. Valorization of raw brewers' spent grain through the production of volatile fatty acids. New Biotechnol. 2020, 57, 4-10. [CrossRef]

115. Bengtsson, S.; Werker, A.; Christensson, M.; Welander, T. Production of polyhydroxyalkanoates by activated sludge treating a paper mill wastewater. Bioresour. Technol. 2008, 99, 509-516. [CrossRef]

116. Carvalho, G.; Pedras, I.; Karst, S.M.; Oliveira, C.S.S.; Duque, A.F.; Nielsen, P.H.; Reis, M.A.M. Functional redundancy ensures performance robustness in 3-stage PHA-producing mixed cultures under variable feed operation. New Biotechnol. 2018, 40, 207-217. [CrossRef]

117. Reis, M.A.M.; Serafim, L.S.; Lemos, P.C.; Ramos, M.; Aguiar, F.R.; Van Loosdrecht, M.C.M. Production of polyhydroxyalkanoates by mixed microbial cultures. Bioprocess. Biosyst. Eng. 2003, 25, 377-385. [CrossRef]

118. Tyagi, V.K.; Lo, S.L. Sludge: A waste or renewable source for energy and resources recovery? Renew. Sustain. Energy Rev. 2013, 25, 708-728. [CrossRef]

119. Bengtsson, S.; Hallquist, J.; Werker, A.; Welander, T. Acidogenic fermentation of industrial wastewaters: Effects of chemostat retention time and $\mathrm{pH}$ on volatile fatty acids production. Biochem. Eng. J. 2008, 40, 492-499. [CrossRef]

120. Pakalapati, H.; Chang, C.-K.; Show, P.L.; Arumugasamy, S.K.; Lan, J.C.-W. Development of polyhydroxyalkanoates production from waste feedstocks and applications. J. Biosci. Bioeng. 2018, 126, 282-292. [CrossRef]

121. Estévez-Alonso, Á.; Pei, R.; van Loosdrecht, M.C.M.; Kleerebezem, R.; Werker, A. Scaling-up microbial community-based polyhydroxyalkanoate production: Status and challenges. Bioresour. Technol. 2021, 327, 124790. [CrossRef]

122. Rodriguez-Perez, S.; Serrano, A.; Pantión, A.A.; Alonso-Fariñas, B. Challenges of scaling-up PHA production from waste streams. A review. J. Environ. Manag. 2018, 205, 215-230. [CrossRef]

123. Veolia PHA. Pilot- and full-Scale Production from Domestic Wastewater. Available online: http:/ / www.veolia.com (accessed on 13 August 2021).

124. Chakravarty, P.; Mhaisalkar, V.; Chakrabarti, T. Study on poly-hydroxyalkanoate (PHA) production in pilot scale continuous mode wastewater treatment system. Bioresour. Technol. 2010, 101, 2896-2899. [CrossRef]

125. Morgan-Sagastume, F.; Hjort, M.; Cirne, D.; Gérardin, F.; Lacroix, S.; Gaval, G.; Karabegovic, L.; Alexandersson, T.; Johansson, P.; Karlsson, A.; et al. Integrated production of polyhydroxyalkanoates (PHAs) with municipal wastewater and sludge treatment at pilot scale. Bioresour. Technol. 2015, 181, 78-89. [CrossRef]

126. Tamis, J.; Mulders, M.; Dijkman, H.; Rozendal, R.; van Loosdrecht, M.C.M.; Kleerebezem, R. Pilot-Scale Polyhydroxyalkanoate Production from Paper Mill Wastewater: Process Characteristics and Identification of Bottlenecks for Full-Scale Implementation. J. Environ. Eng. 2018, 144, 4018107. [CrossRef]

127. Kinyua, M.N.; Miller, M.W.; Wett, B.; Murthy, S.; Chandran, K.; Bott, C.B. Polyhydroxyalkanoates, triacylglycerides and glycogen in a high rate activated sludge A-stage system. Chem. Eng. J. 2017, 316, 350-360. [CrossRef] 
128. Ntaikou, I.; Valencia Peroni, C.; Kourmentza, C.; Ilieva, V.I.; Morelli, A.; Chiellini, E.; Lyberatos, G. Microbial bio-based plastics from olive-mill wastewater: Generation and properties of polyhydroxyalkanoates from mixed cultures in a two-stage pilot scale system. J. Biotechnol. 2014, 188, 138-147. [CrossRef]

129. Jia, Q.; Xiong, H.; Wang, H.; Shi, H.; Sheng, X.; Sun, R.; Chen, G. Production of polyhydroxyalkanoates (PHA) by bacterial consortium from excess sludge fermentation liquid at laboratory and pilot scales. Bioresour. Technol. 2014, 171, 159-167. [CrossRef]

130. Tamis, J.; Lužkov, K.; Jiang, Y.; van Loosdrecht, M.C.M.; Kleerebezem, R. Enrichment of Plasticicumulans acidivorans at pilot-scale for PHA production on industrial wastewater. J. Biotechnol. 2014, 192, 161-169. [CrossRef]

131. Conca, V.; da Ros, C.; Valentino, F.; Eusebi, A.L.; Frison, N.; Fatone, F. Long-term validation of polyhydroxyalkanoates production potential from the sidestream of municipal wastewater treatment plant at pilot scale. Chem. Eng. J. 2020, 390, 124627. [CrossRef]

132. Valentino, F.; Moretto, G.; Lorini, L.; Bolzonella, D.; Pavan, P.; Majone, M. Pilot-Scale Polyhydroxyalkanoate Production from Combined Treatment of Organic Fraction of Municipal Solid Waste and Sewage Sludge. Ind. Eng. Chem. Res. 2019, 58, 12149-12158. [CrossRef]

133. Werker, A.; Bengtsson, S.; Korving, L.; Hjort, M.; Anterrieu, S.; Alexandersson, T.; Johansson, P.; Karlsson, A.; Karabegovic, L.; Magnusson, P.; et al. Consistent production of high quality PHA using activated sludge harvested from full scale municipal wastewater treatment-PHARIO. Water Sci. Technol. 2018, 78, 2256-2269. [CrossRef]

134. European Union. Directive (EU) 2019/904 of the European Parliament and of the Council of 5 June 2019 on the Reduction of the Impact of Certain Plastic Products on the Environment; European Union: Luxembourg, 2019.

135. Laspidou, C.S.; Rittmann, B.E. A unified theory for extracellular polymeric substances, soluble microbial products, and active and inert biomass. Water Res. 2002, 36, 2711-2720. [CrossRef]

136. Lotti, T.; Carretti, E.; Berti, D.; Martina, M.R.; Lubello, C.; Malpei, F. Extraction, recovery and characterization of structural extracellular polymeric substances from anammox granular sludge. J. Environ. Manag. 2019, 236, 649-656. [CrossRef] [PubMed]

137. Wingender, J.; Neu, T.R.; Flemming, H.-C. What are bacterial extracellular polymeric substances? In Microbial Extracellular Polymeric Substances; Wingender, J., Neu, T.R., Flemming, H.-C., Eds.; Springer: Berlin/Heidelberg, Germany, 1999; pp. 1-19. ISBN 978-3-642-60147-7.

138. Feng, C.; Lotti, T.; Canziani, R.; Lin, Y.; Tagliabue, C.; Malpei, F. Extracellular biopolymers recovered as raw biomaterials from waste granular sludge and potential applications: A critical review. Sci. Total Environ. 2021, 753, 142051. [CrossRef] [PubMed]

139. Costerton, J.W.; Irvin, R.T.; Cheng, K.J. The bacterial glycocalyx in nature and disease. Annu. Rev. Microbiol. 1981, 35, $299-324$. [CrossRef] [PubMed]

140. Flemming, H.C.; Wingender, J.; Szewzyk, U.; Steinberg, P.; Rice, S.A.; Kjelleberg, S. Biofilms: An emergent form of bacterial life. Nat. Rev. Microbiol. 2016, 14, 563-575. [CrossRef]

141. Nielsen, P.H.; Jahn, A.; Palmgren, R. Conceptual model for production and composition of exopolymers in biofilms. Water Sci. Technol. 1997, 36, 11-19. [CrossRef]

142. Dignac, M.F.; Urbain, V.; Rybacki, D.; Bruchet, A.; Snidaro, D.; Scribe, P. Chemical description of extracellular polymers: Implication on activated sludge floc structure. In Proceedings of the Water Science and Technology, Vancouver, BC, Canada, 21-26 June 1998; Volume 38, pp. 45-53.

143. Badireddy, A.R.; Chellam, S.; Gassman, P.L.; Engelhard, M.H.; Lea, A.S.; Rosso, K.M. Role of extracellular polymeric substances in bioflocculation of activated sludge microorganisms under glucose-controlled conditions. Water Res. 2010, 44, 4505-4516. [CrossRef]

144. Adav, S.S.; Lee, D.-J. Extraction of extracellular polymeric substances from aerobic granule with compact interior structure. J. Hazard. Mater. 2008, 154, 1120-1126. [CrossRef]

145. Guibaud, G.; Comte, S.; Bordas, F.; Dupuy, S.; Baudu, M. Comparison of the complexation potential of extracellular polymeric substances (EPS), extracted from activated sludges and produced by pure bacteria strains, for cadmium, lead and nickel. Chemosphere 2005, 59, 629-638. [CrossRef]

146. Comte, S.; Guibaud, G.; Baudu, M. Biosorption properties of extracellular polymeric substances (EPS) towards Cd, Cu and Pb for different $\mathrm{pH}$ values. J. Hazard. Mater. 2008, 151, 185-193. [CrossRef]

147. Pronk, M.; Giesen, A.; Thompson, A.; Robertson, S.; Van Loosdrecht, M. Aerobic granular biomass technology: Advancements in design, applications and further developments. Water Pract. Technol. 2017, 12, 987-996. [CrossRef]

148. Lin, Y.; de Kreuk, M.; van Loosdrecht, M.C.M.; Adin, A. Characterization of alginate-like exopolysaccharides isolated from aerobic granular sludge in pilot-plant. Water Res. 2010, 44, 3355-3364. [CrossRef]

149. Flez, S.; Al-Zuhairy, S.; Aarstad, O.A.; van Loosdrecht, M.C.M.; Lin, Y.M. Extraction of Structural Extracellular Polymeric Substances from Aerobic Granular Sludge. JoVE 2016, 115, e54534. [CrossRef]

150. Comte, S.; Guibaud, G.; Baudu, M. Biosorption properties of extracellular polymeric substances (EPS) resulting from activated sludge according to their type: Soluble or bound. Process. Biochem. 2006, 41, 815-823. [CrossRef]

151. Guo, H.; Felz, S.; Lin, Y.; van Lier, J.B.; de Kreuk, M. Structural extracellular polymeric substances determine the difference in digestibility between waste activated sludge and aerobic granules. Water Res. 2020, 181, 115924. [CrossRef]

152. Kaumera. Available online: https:// kaumera.com/english/ (accessed on 13 August 2021).

153. Luiz de Sousa Rollemberg, S.; Queiroz de Oliveira, L.; Nascimento de Barros, A.; Igor Milen Firmino, P.; Bezerra dos Santos, A. Pilot-scale aerobic granular sludge in the treatment of municipal wastewater: Optimizations in the start-up, methodology of sludge discharge, and evaluation of resource recovery. Bioresour. Technol. 2020, 311, 123467. [CrossRef] 
154. Van Leeuwen, K.; De Vries, E.; Roest, K.; Koop, S. The Energy \& Raw Materials Factory: Role and Potential Contribution to the Circular Economy of the Netherlands. Environ. Manage. 2018, 61, 786-795. [CrossRef]

155. Oliveira, A.S.; Amorim, C.L.; Ramos, M.A.; Mesquita, D.P.; Inocêncio, P.; Ferreira, E.C.; van Loosdrecht, M.; Castro, P.M.L. Variability in the composition of extracellular polymeric substances from a full-scale aerobic granular sludge reactor treating urban wastewater. J. Environ. Chem. Eng. 2020, 8, 104156. [CrossRef]

156. Boleij, M.; Pabst, M.; Neu, T.R.; van Loosdrecht, M.C.M.; Lin, Y. Identification of Glycoproteins Isolated from Extracellular Polymeric Substances of Full-Scale Anammox Granular Sludge. Environ. Sci. Technol. 2018, 52, 13127-13135. [CrossRef]

157. Wang, W.; Yan, Y.; Zhao, Y.; Shi, Q.; Wang, Y. Characterization of stratified EPS and their role in the initial adhesion of anammox consortia. Water Res. 2020, 169, 115223. [CrossRef]

158. Pronk, M.; de Kreuk, M.K.; de Bruin, B.; Kamminga, P.; Kleerebezem, R.; van Loosdrecht, M.C.M. Full scale performance of the aerobic granular sludge process for sewage treatment. Water Res. 2015, 84, 207-217. [CrossRef]

159. Lackner, S.; Gilbert, E.M.; Vlaeminck, S.E.; Joss, A.; Horn, H.; van Loosdrecht, M.C.M. Full-scale partial nitritation/anammox experiences-An application survey. Water Res. 2014, 55, 292-303. [CrossRef]

160. Lin, Y.M.; Sharma, P.K.; van Loosdrecht, M.C.M. The chemical and mechanical differences between alginate-like exopolysaccharides isolated from aerobic flocculent sludge and aerobic granular sludge. Water Res. 2013, 47, 57-65. [CrossRef]

161. Felz, S.; Vermeulen, P.; van Loosdrecht, M.C.M.; Lin, Y.M. Chemical characterization methods for the analysis of structural extracellular polymeric substances (EPS). Water Res. 2019, 157, 201-208. [CrossRef]

162. Felz, S. Structural Extracellular Polymeric Substances from Aerobic Granular Sludge. Ph.D. Thesis, Delft University of Technology, Delft, The Netherlands, 2019.

163. Cetin, E.; Karakas, E.; Dulekgurgen, E.; Ovez, S.; Kolukirik, M.; Yilmaz, G. Effects of high-concentration influent suspended solids on aerobic granulation in pilot-scale sequencing batch reactors treating real domestic wastewater. Water Res. 2018, 131, 74-89. [CrossRef]

164. Long, B.; Yang, C.-Z.; Pu, W.-H.; Yang, J.-K.; Jiang, G.-S.; Dan, J.-F.; Li, C.-Y.; Liu, F.-B. Rapid cultivation of aerobic granular sludge in a pilot scale sequencing batch reactor. Bioresour. Technol. 2014, 166, 57-63. [CrossRef] [PubMed]

165. Tang, C.J.; Duan, C.S.; Yu, C.; Song, Y.X.; Chai, L.Y.; Xiao, R.; Wei, Z.; Min, X.B. Removal of nitrogen from wastewaters by anaerobic ammonium oxidation (ANAMMOX) using granules in upflow reactors. Environ. Chem. Lett. 2017, 15, 311-328. [CrossRef]

166. Karakas, I.; Sam, S.B.; Cetin, E.; Dulekgurgen, E.; Yilmaz, G. Resource recovery from an aerobic granular sludge process treating domestic wastewater. J. Water Process. Eng. 2020, 34, 101148. [CrossRef]

167. Lin, Y.M.; Nierop, K.G.J.; Girbal-Neuhauser, E.; Adriaanse, M.; van Loosdrecht, M.C.M. Sustainable polysaccharide-based biomaterial recovered from waste aerobic granular sludge as a surface coating material. Sustain. Mater. Technol. 2015, 4, 24-29. [CrossRef]

168. Lotti, T.; Carretti, E.; Berti, D.; Montis, C.; Del Buffa, S.; Lubello, C.; Feng, C.; Malpei, F. Hydrogels formed by anammox extracellular polymeric substances: Structural and mechanical insights. Sci. Rep. 2019, 9, 11633. [CrossRef]

169. Zlopasa, J.; Koenders, E.A.B.; Picken, S.J. Using bio-based polymers for curing cement-based materials. In Proceedings of the 1st Ageing of Materials \& Structures Conference, Delft, The Netherlands, 26-28 May 2014.

170. Guibaud, G.; Bhatia, D.; D’Abzac, P.; Bourven, I.; Bordas, F.; van Hullebusch, E.D.; Lens, P.N.L. Cd(II) and Pb(II) sorption by extracellular polymeric substances (EPS) extracted from anaerobic granular biofilms: Evidence of a pH sorption-edge. J. Taiwan Inst. Chem. Eng. 2012, 43, 444-449. [CrossRef]

171. Li, N.; Wei, D.; Wang, S.; Hu, L.; Xu, W.; Du, B.; Wei, Q. Comparative study of the role of extracellular polymeric substances in biosorption of $\mathrm{Ni}$ (II) onto aerobic/anaerobic granular sludge. J. Colloid Interface Sci. 2017, 490, 754-761. [CrossRef]

172. Suh, J.H.; Kim, D.S. Comparison of different sorbents (inorganic and biological) for the removal of Pb2+ from aqueous solutions. J. Chem. Technol. Biotechnol. 2000, 75, 279-284. [CrossRef]

173. Kim, N.K.; Mao, N.; Lin, R.; Bhattacharyya, D.; van Loosdrecht, M.C.M.; Lin, Y. Flame retardant property of flax fabrics coated by extracellular polymeric substances recovered from both activated sludge and aerobic granular sludge. Water Res. 2020, 170, 115344. [CrossRef]

174. Nouha, K.; Kumar, R.S.; Balasubramanian, S.; Tyagi, R.D.; Gk, Q. Critical review of EPS production, synthesis and composition for sludge flocculation. J. Environ. Sci. 2018, 66, 225-245. [CrossRef]

175. ROYAL HASKONINGDHV Kaumera Nereda ${ }^{\circledR}$ Gum. Available online: https://global.royalhaskoningdhv.com/services/a-zservices/kaumera (accessed on 13 August 2021). 